UNIVERSIDADE DE SÃO PAULO

FACULDADE DE FILOSOFIA, LETRAS E CIÊNCIAS HUMANAS DEPARTAMENTO DE LETRAS MODERNAS

PROGRAMA DE PÓS-GRADUAÇÃO EM LÍNGUA ESPANHOLA E LITERATURAS ESPANHOLA E HISPANO-AMERICANA

MARCELO MACIEL CERIGIOLI

RAFAEL ALBERTI: LEITURAS DO MUSEU DO PRADO

Versão Corrigida. O exemplar original se encontra disponível no CAPH da FFLCH

São Paulo

2011 
UNIVERSIDADE DE SÃO PAULO

FACULDADE DE FILOSOFIA, LETRAS E CIÊNCIAS HUMANAS DEPARTAMENTO DE LETRAS MODERNAS

PROGRAMA DE PÓS-GRADUAÇÃO EM LÍNGUA ESPANHOLA E LITERATURAS ESPANHOLA E HISPANO-AMERICANA

\author{
MARCELO MACIEL CERIGIOLI
}

\title{
RAFAEL ALBERTI: LEITURAS DO MUSEU DO PRADO
}

Versão Corrigida. O exemplar original se encontra disponível no CAPH da FFLCH

Dissertação apresentada ao Programa de Pós-Gradução em Língua Espanhola e Literaturas Espanhola e Hispano-Americana do Departamento de Letras Modernas da Faculdade de Filosofia, Letras e Ciências Humanas da Universidade de São Paulo para a obtenção do título de Mestre em Letras.

De Acordo,

Orientadora: Prof ${ }^{\mathrm{a}}$. Dra‥ Valeria De Marco

São Paulo

2011 


\section{Agradecimentos}

À Profa. Dra. Valeria de Marco, pela oportunidade, paciência, orientação e pela contribuição para o meu crescimento acadêmico e pessoal.

Aos meus pais, meus irmãos e demais familiares pela compreensão e apoio incondicionais.

A todos os meus amigos pela dedicação, pelos momentos compartilhados de felicidade e companheirismo.

Aos colegas do Grupo de Estudo pela convivência, apoio, conhecimento e crescimento.

Aos funcionários do Serviço de Pós-Graduação, pela prontidão e atenção. 


\section{Resumo}

A presente dissertação analisa os livros sobre o Museu do Prado, A la pintura (1948) e Noche de guerra en el Museo del Prado (1956), ambos do escritor espanhol Rafael Alberti, escritos na Argentina, durante seu longo exílio. A investigação parte da contextualização de Alberti, que nos leva a uma aproximação ao tema, o Museu do Prado, tratado de maneira diferente nas duas obras. Na sequência, é analisada $A$ la pintura e, em seguida, a peça de teatro Noche de guerra en el Museo del Prado.

Palavras-Chave: Rafael Alberti, Exílio espanhol de 1939, Poesia espanhola do século XX, Teatro espanhol do século XX, Museu do Prado. 


\begin{abstract}
This study analyzes the books about the Prado Museum, A la pintura (1948) and Noche de guerra en el Museo del Prado (1956), both of spanish writer Rafael Alberti, written in Argentina, during his long exile. The investigation parts from the context of Alberti, that leads to an approach to the subject, the Prado Museum, treated differently in the two books. In the sequence is analyzed $A$ la pintura and then the piece of theater Noche de guerra en el Museo del Prado.
\end{abstract}

Keywords: Rafael Alberti, Spanish exile of 1939, Twentieth-century Spanish poetry, Twentieth-century Spanish theater, Prado Museum. 


\section{Resumen}

Este estudio analiza los libros sobre el Museo del Prado, A la pintura (1948) y Noche de guerra en el Museo del Prado (1956), ambos del escritor español Rafael Alberti, escritos en Argentina, durante su largo exilio. La investigación parte del contexto de Alberti, que nos conduce a una aproximación al tema, el Museo del Prado, tratado de manera diferente en las dos obras. En la secuencia, se analiza $A$ la pintura y, en seguida, la pieza de teatro Noche de guerra en el Museo del Prado.

Palabras Clave: Rafael Alberti, Exilio español de 1939, Poesía española del siglo XX, Teatro español del siglo XX, Museo del Prado. 


\section{Sumário}

INTRODUÇÃO

I. RAFAEL ALBERTI .................................................................... 11

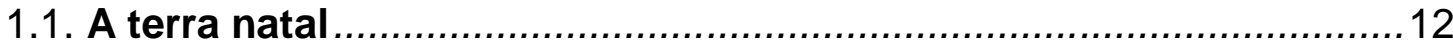

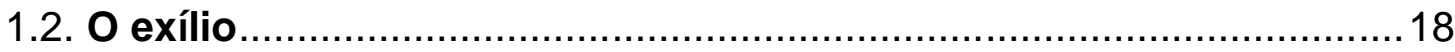

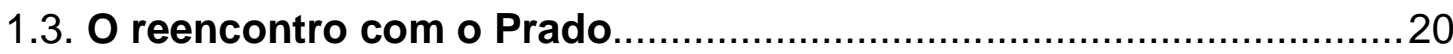

II. A LA PINTURA

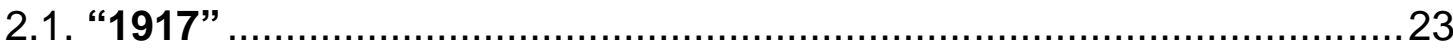

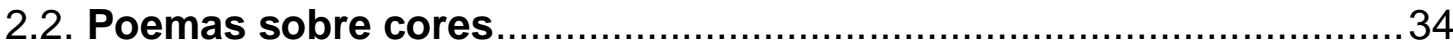

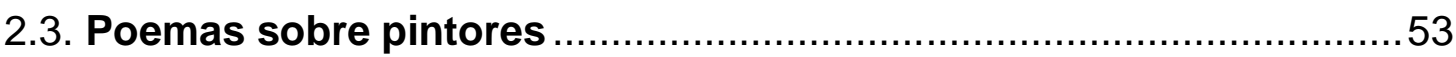

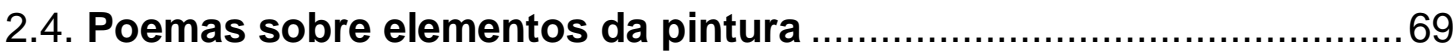

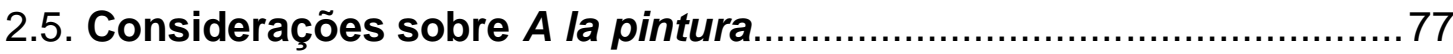

III. NOCHE DE GUERRA EN EL MUSEO DEL PRADO ...................... 80

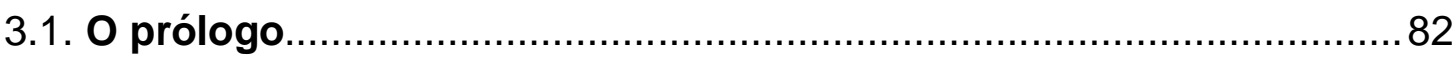

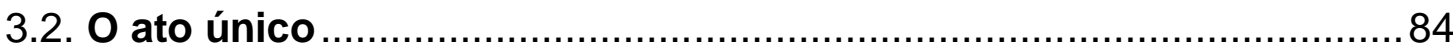

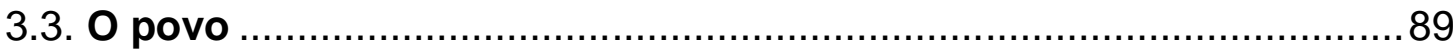

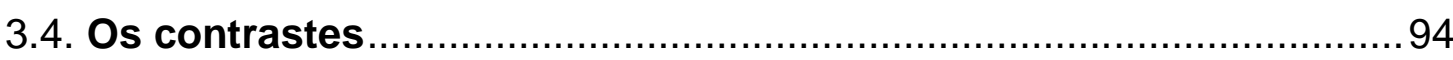

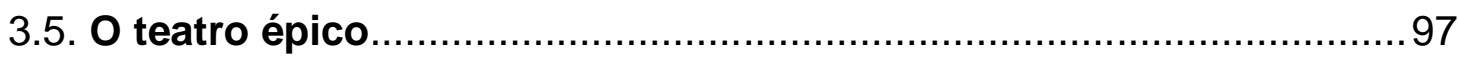

3.6. Considerações sobre Noche de guerra en el Museo del Prado ........99

CONSIDERAÇÕES FINAIS ....................................................... 103

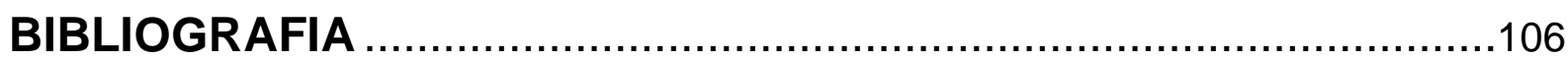

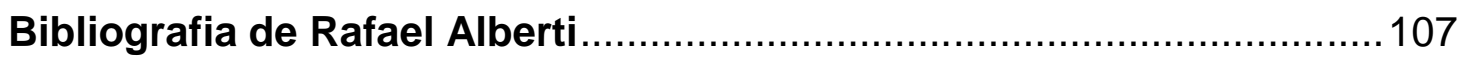

Bibliografia sobre Rafael Alberti ................................................... 107

Bibliografia geral ..................................................................... 111 


\section{INTRODUÇÃO}

Desde mayo de 1917, año en que tuve que dejar, con mi familia, mi ciudad natal, El puerto de Santa María, en la maravillosa y mítica bahía gaditana, para instalarme definitivamente en Madrid, puedo decir, sin exageración, que elegí como mi gran vivienda el Museo del Prado.

Rafael Alberti 
O Museu do Prado, localizado em Madri, possui um acervo de grande relevância mundial e é considerado muito importante para a formação do espanhol Rafael Alberti como artista, político e intelectual. No entanto, durante o longo exílio, foi separado desta casa da pintura. As saudades da terra natal e a importância do museu inspiraram o artista a escrever duas obras em homenagem ao Prado: A la pintura (1948) e Noche de guerra en el Museo del Prado (1956)

O objetivo dessa dissertação constitui a análise dos dois livros sobre o Museu do Prado. O presente estudo justifica-se pela necessidade de se compreender melhor os poemas de A la pintura, o teatro em Noche de guerra en el Museo del Prado, a relação entre as obras, além de ajudar a divulgar mais no Brasil o autor Rafael Alberti e sua produção artística.

O corpus desta pesquisa é composto pelo livro de poemas $A$ la pintura e pela peça de teatro Noche de guerra en el Museo del Prado. Como o livro de poemas possui, além do "1917", três tipos de poemas —os dedicados às cores, os que homenageiam os pintores e os que tratam dos elementos da pintura, para que pudéssemos abarcar a diversidade e a riqueza do livro, selecionamos o poema introdutório - "1917"- e mais seis poemas de cada tipo como focos da análise em A la pintura.

Para cumprir nosso objetivo, apresentamos o contexto histórico da vida e obra de Rafael Alberti no primeiro capítulo da dissertação. Assim, tratamos de apresentar a infância e a adolescência do autor em sua terra natal, o longo e fértil período de exílio, o retorno à Espanha, com o reencontro com o Prado, e os últimos anos de vida.

O segundo capítulo é dedicado à obra $A$ la pintura, começando pelo poema "1917" e, na sequência, os seis poemas existentes sobre cores — "Azul", "Rojo", 
"Amarillo", "Verde", "Negro" e "Blanco", seis poemas sobre pintores — "Giotto", "Leonardo", “El Bosco", “El Greco", "Goya” e "Picasso", seis sobre elementos da pintura —_A la retina", "A la paleta", "A la perspectiva", "Al claroscuro", "A la gracia" e "A la acuarela"-e, por último, expomos as considerações sobre o livro.

O terceiro capítulo trata de Noche de guerra en el Museo del Prado, começando pelo prólogo, estudando o ato único, o povo, os contrastes, o teatro épico e, por último, fazemos uma interpretação da peça.

Por fim, serão apresentadas as considerações finais da dissertação. 


\section{RAFAEL ALBERTI}

Cuando después de casi treinta y nueve años de exilio pude regresar a España, al llegar a Madrid lo primero que hice, como había hecho en 1917, fue correr al Museo del Prado.

Rafael Alberti 


\title{
1.1. A terra natal
}

Rafael Alberti Merello nasceu no dia 16 de dezembro de 1902 em El Puerto de Santa Maria —Cádiz, sendo o quinto dos seis filhos do casal Agustín e María. Desde a infância já anunciava sua primeira vocação, a pintura, pois desenhava os barcos e os transatlânticos que chegavam em sua cidade natal.

Em 1917, quando passava por grandes dificuldades financeiras, seu pai foi trabalhar em Madri, levando junto toda a família. Com tal mudança, surgiu a oportunidade de Alberti visitar o Museu do Prado pela primeira vez, o que marcou sua vida, dando início a uma grande paixão que mais tarde se refletiu nas obras do artista:

\begin{abstract}
Desde mayo de 1917 [...] puedo decir, sin exageración, que elegí como mi gran vivienda el Museo del Prado. Yo, entonces, no era poeta, no había despertado aún a la poesía, creyendo ciegamente que sólo iba para pintor. [...] quise primero dibujar, hacer academias, compartiendo mis visitas al Museo del Prado con mis mañanas del Casón, un precioso palacete del rey Felipe IV, en donde llegué a dibujar, aprendiéndolas de memoria, cuantas estatuas griegas y romanas se levantaban en sus salas.
\end{abstract}

O Museu aos poucos foi se tornando sua grande escola de arte, além de uma segunda casa, onde passava longos períodos dos dias estudando desenho e pintura a partir do acervo de quadros e esculturas, o que resultou, em 1920, em sua primeira exposição coletiva, concorrendo com sua pintura no Salão Nacional de Outono de Madri. Esse ano, aliás, é também marcado pelo impacto da morte de seu pai e, por conseqüência, segundo o artista, pelo nascimento de seus primeiros poemas.

\footnotetext{
${ }^{1}$ ALBERTI, Rafael. La arboleda perdida. Tercero y cuarto libros (1931 - 1987). Madrid: Alianza, 1998, p. 96.
} 
Dois anos mais tarde, em 1922, Alberti publicou seus primeiros versos na revista Horizonte e expôs seus quadros vanguardistas no Ateneu de Madri. Em 1923 passou a se dedicar exclusivamente à poesia, escrevendo seu primeiro livro de poemas: Mar y tierra que no ano seguinte foi rebatizado de Marinero en tierra.

Em 1924, em constantes visitas à Residência dos Estudantes de Madri, conviveu com García Lorca, Salinas, Guillén, Aleixandre, Dámaso Alonso, José Bergamín, Gerardo Diego, grupo de poetas vanguardistas conhecido como a Geração de 27, além de outros intelectuais como o pintor Dali e o cineasta Buñuel.

Daquele momento em diante começou a publicar versos em diversas revistas e ganhou o Prêmio Nacional de Literatura com o livro Marinero en tierra. No entanto, como Alberti possuía uma inclinação para a política, nunca separou seu trabalho intelectual de seus ideais políticos. Ao casar-se com Maria Teresa León em 1930, ele ganhou uma grande companheira de militância.

Em 1931 filiou-se ao Partido Comunista, o que se refletiu em seus poemas, escritos com palavras duras, como manifestos, que colava nas paredes das casas madrilenas. No contexto da politização da cultura, em 1932, com o apoio da Junta de Ampliação de Estudos de Madrid, Alberti e Maria Teresa León viajaram pela Europa para estudar os novos movimentos cênicos. Nesta viagem conheceram Brecht e Piscator em Berlim:

Durante nuestra estancia en Paris, asistíamos a cuanta representación teatral de teatro joven de vanguardia existía. Solíamos mandar a la Junta de Ampliación de Estudios de Madrid, por la que estábamos pensionados para estudiar los movimientos nuevos escénicos de Europa, un informe cada dos meses. Y así nos recorrimos Francia, Bélgica, Alemania y la Unión Soviética. Era aquél un gran momento para el teatro, a pesar de que Hitler acababa de asaltar el poder en Alemania y en la nueva e ilusa República Española se 
empezaba a gestar la sublevación militar de 18 de julio, que nos llevaría a casi tres años de guerra civil. Pero a mí entonces me apasionaba el teatro en aquel mismo momento en que Federico García Lorca lanzaba el suyo de La Barraca por los pueblos de España. Nosotros volvimos a Madrid para crear algo muy diferente: la revista Octubre, una revista de literatura revolucionaria, en la que colaboraron Luís Buñuel, Antonio Machado, Arturo Serrano Plaja, César M. Arconada y Luís Cernuda al lado de poetas franceses como Louis Aragón, Paul Éluard [...]A finales de 1932 me encontraba en Berlin con Maria Teresa, pensionado por la Junta de Ampliación de Estudios para estudiar los movimientos teatrales europeos. Allí conocía a Erwin Piscator, gran director de escena, a Bertolt Brecht, ambos muy jóvenes aún. ${ }^{2}$

No contato com os movimentos artísticos europeus, o casal retornou à Espanha para fundar em 1934 a revista de literatura revolucionária Octubre ${ }^{3}$, como explica Alberti ${ }^{4}$ " "la primera española que dio la alerta en el campo de la cultura y que agrupó a una serie de jóvenes escritores". Ainda em 1934, Alberti assistiu como convidado na União Soviética ao Primeiro Congresso de Escritores Soviéticos:

El hambre y la desocupación andaban por las calles, cruzadas de las escuadras nazis, que pateaban las aceras, salpicando de agua de los charcos a los aterrados transeúntes. Hitler se disponía ya, como en un gran guiñol, a instalar sus absurdos bigotes y brazos gesticulantes tras el humo y las llamas del incendio del Reichstag. En ese momento se me ocurrió viajar, por primera vez, a la Unión Soviética, que fue para mí entonces como realizar un viaje del fondo de la noche al centro de la luz [...] Tres días llevábamos ya en Moscú, cuando la Unión Internacional de Escritores Revolucionarios (MORP) nos invitó a quedarnos con ellos. ${ }^{5}$

Pouco tempo depois, na Espanha eclodia a Guerra Civil Espanhola (1936-1939). Segundo Romero Salvadó, este "foi principalmente um conflito local, uma tentativa

\footnotetext{
${ }^{2}$ ALBERTI, Rafael. La arboleda perdida. Tercero y cuarto libros (1931 - 1987). Madrid: Alianza, 1998, p. 25-26.

${ }^{3} \mathrm{O}$ título Octubre trás clara referência à Revolução de Outubro, na qual o Partido Bolchevique, liderado por Lênin, derrubou o governo provisório e implantou o governo socialista soviético.

${ }^{4}$ ALBERTI, Rafael, op. cit., p. 72.

${ }^{5}$ Ibidem, p. 26.
} 
brutal de resolver, por meios militares, um grande número de questões sociais e políticas que dividiram os espanhóis por várias gerações [...]”6.

Nesse contexto, em 1936, Rafael Alberti assumiu o cargo de Secretário da Aliança de Intelectuais Antifascistas, por onde passavam artistas e escritores vindos de diversos países. No mesmo ano, Alberti fundou na Espanha a revista antifascista El mono azul ${ }^{7}$, em formato de folheto, na defesa da república e democracia, destinada à instrução militar, política e literária dos milicianos.

Apreciador dos quadros do Prado e consciente da diversidade e importância do Museu para o país, Alberti ficou muito preocupado com o risco que esse patrimônio cultural nacional passou a correr a partir do avanço das tropas de Franco sobre a capital, já que o Museu do Prado havia se tornado um dos alvos dos bombardeios aéreos.

Sendo assim, durante a guerra, em sua intensiva participação na Aliança, Alberti fez parte da Junta de Salvamento Artístico. Nesta, ele participou da missão de salvar os quadros mais significativos e valiosos do Prado e de evacuar as obras de arte do Museu para evitar sua destruição. Assim, "Las meninas, El dos de mayo, y otros tesoros artísticos fueron evacuados a Valencia, primero, a Barcelona después $[\ldots]^{\prime \prime}$, acontecimento que inspiraria mais tarde sua obra teatral Noche de guerra en el Museo del Prado, publicada em 1956.

Com a ajuda de sua esposa, Maria Teresa León, e com a autorização do governo republicano, Alberti entrou no Museu para resgatar os quadros Las meninas e

\footnotetext{
${ }^{6}$ ROMERO SALVADÓ, Francisco. A Guerra Civil Espanhola. Trad: Bárbara Duarte. Rio de Janeiro: Jorge Zahar, 2008, p. 7.

${ }^{7} \mathrm{O}$ título El mono azul faz referência ao macacão dos trabalhadores.

${ }^{8}$ CRISPIN, John. Los tres paraísos: religioso, estético y marxista en Noche de guerra en el Museo del Prado. Insula, Madrid, nº 40 (467), p. 3, oct. de 1985.
} 
Carlos V en la Batalla de Mühlberg, que o Ministério de Belas Artes pretendia retirar de Madri para que não corressem o risco de serem danificados pelos bombardeios ${ }^{9}$ :

\begin{abstract}
Desde 1917 hasta la insurrección militar de julio de 1936, el Museo del Prado había sido mi casa juvenil, la cita con las novias, con los amigos pintores y poetas, ya en esos años poeta yo, a partir de 1924, pero siempre apasionadísimo de la pintura. Pero el Museo del Prado cerró sus puertas al público a partir de los primeros bombardeos de Madrid por la aviación franquista, cuyas bombas lo habían alcanzado, cayendo precisamente algunas en la sala Velásquez [...] todo el Madrid intelectual y artístico que amaba y se enorgullecía de poseer una de las pinacotecas más ricas y asombrosas del mundo. También para la Alianza de Intelectuales Antifascistas, de la que yo era secretario [...] Pero un atardecer de ese mismo mes de noviembre, María Teresa y yo, con un permiso del jefe del Gobierno, Francisco Largo Caballero, entramos en el Prado para iniciar, con un primer envío, el salvamento de las principalísimas obras que el Ministerio de Bellas Artes de la Republica se proponía sacar de Madrid [...] Carlos V en la batalla de Mühlberg, de Tiziano, y Las meninas, de Velásquez [...] Agonía sin fin. Lo dije [...] a un diario, en una entrevista: "Gran parte de la pintura española está enferma. Y en algunas obras de Velázquez hay signos mortales". Esto lo sabía bien la dirección del Museo del Prado, pero el franquismo se había interesado más en coleccionar, en juntar a los vivos que había matado en la guerra que en salvar tantas maravillosas cosas que estaban agonizando en el país. ${ }^{10}$
\end{abstract}

Em plena Guerra Civil Espanhola, mais especificamente no ano de 1937, Alberti voltou à União Soviética para participar ativamente da organização do Segundo Congresso Internacional de Escritores Soviéticos. Em Moscou, realizou inclusive uma entrevista com Stalin.

Mais tarde, em 1939, ocorreram fugas em massa na Espanha, o que resultou no fechamento das fronteiras da França e na criação de campos de concentração franceses para os que tentassem escapar do regime ditatorial do general Franco.

\footnotetext{
${ }^{9}$ Esse episódio foi relatado por Alberti em uma crônica chamada "Mi última Visita al Museo del Prado": ALBERTI, Rafael. Mi última visita al Museo del Prado. In: Relatos y prosa. Barcelona: Bruguera, 1980, p. 117-122.

${ }^{10}$ ALBERTI, Rafael. La arboleda perdida. Tercero y cuarto libros (1931-1987). Madrid: Alianza, 1998, p. 97-100.
} 
A ligação entre a realidade local e o contexto internacional foi a razão crucial

para a decisiva vitória da direita nacionalista do general Franco, como explica Buades:

O espírito da II República, liberal, democrático, socialista, laico e reformador, ia à contramão da tendência geral do mundo ocidental na década de 1930. Cada vez restava menos espaço para uma "república de trabalhadores" num mundo que caminhava aceleradamente para a polarização entre o totalitarismo de direita e o totalitarismo de esquerda. Quando se proclamou a república socialdemocrática espanhola já havia cinco anos que sua homóloga portuguesa tinha sucumbido ao autoritarismo militar. ${ }^{11}$

Com os grandes bombardeios e a carnificina das batalhas, a Espanha estava arrasada no final da Guerra Civil. Vieram décadas de ditadura fascista, regime que perseguiu e tentou calar a inteligência espanhola. Assim, muitos morreram, foram assassinados ou fugiram para o longo exílio, como explica Romero Salvadó:

Post-Bellum, os vencedores liderados pelo general Franco perpetuaram a atmosfera da Guerra Civil, desfrutaram do espólio da vitória e passaram a reescrever a história. A outra metade do país enfrentaria décadas de exílio, repressão e silêncio. Só 40 anos depois, a Terceira Espanha ${ }^{12}$, do diálogo e do compromisso, teria chance de ser ouvida novamente. ${ }^{13}$

\footnotetext{
${ }^{11}$ BUADES, Josep M. Entre mares. Uma interpretação da História Contemporânea da Península Ibérica. Vol. 1. São Paulo: Raimundo Lúlio, 2009, p. 314.

12 Romero Salvadó define "Terceira Espanha" como uma grande multidão, muitas vezes ignorada pela sua passividade, que foi arrastada para a guerra por medo ou repugnância.

${ }^{13}$ ROMERO SALVADÓ, Francisco. A Guerra Civil Espanhola. Trad: Bárbara Duarte. Rio de Janeiro: Jorge Zahar, 2008, p. 135.
} 


\subsection{O exílio}

Depois da derrota republicana na Guerra Civil Espanhola, Alberti e sua esposa instalaram-se em Paris em 1939. No ano seguinte, foram para a Argentina, local onde permaneceriam até os anos 60.

No exílio, como poeta já consagrado, Alberti resolveu retomar uma grande paixão de sua vida, que estava adormecida, publicando em 1948 um livro de poemas em homenagem à pintura-escrito entre 1945 e 1948, com o título de $A$ la pintura Poema del color y la línea. Assim, o escritor experimentou a pintura como temática e expressividade em poemas, unindo duas vertentes de sua vida artística, a pintura e a poesia, em homenagem ao Museu do Prado, considerado por ele a casa da pintura e a sua própria casa.

Alberti possuía uma paixão pela pintura e, em particular, uma forte ligação emocional em relação às obras do Museu do Prado. No exílio, as saudades do Prado, que simbolizam a Espanha, criaram um de seus livros mais expressivos, no qual o autor recorreu à evocação de uma experiência pictórica juvenil para compor os 59 poemas ${ }^{14}$ :

En 1945, año en que terminó la Segunda Guerra Mundial, sentí que me golpeaba fuertemente mi primera vocación, porque sobre todo, la nostalgia del Museo del Prado, en donde había vivido mis más jóvenes años, se me concretó en un libro de poemas titulado $A$ la pintura, que me hizo volver a la experimentación de los colores y la línea, pero esta vez entremezclándolos con la palabra, es decir, con el verso [...] era ya, aunque yo no lo pretendiera expresamente, un autor de poesía visiva, que tanto se llegó a cultivar, más que nunca, en la posguerra. ${ }^{15}$

\footnotetext{
${ }^{14}$ Isso ocorre na $1^{\text {a }}$ versão, publicada em 1948, já que na edição de 1975 o autor acrescentou outros poemas.

${ }^{15}$ ALBERTI, Rafael. La arboleda perdida. Tercero y cuarto libros (1931-1987). Madrid: Alianza, 1998, p. 220.
} 
No início dos anos 50, com novo passaporte, Alberti pôde visitar novamente o leste europeu e, especialmente, a União Soviética —URSS, em 1953. Em 1955 escreveu o ato único de Noche de guerra en el Museo del Prado, tendo terminado de compô-la em 1956, com a produção do prólogo sugerido por Brecht ${ }^{16}$.

Assim, do comunismo ao teatro épico, Alberti percorreu um longo caminho: desde a aproximação à doutrina de Lênin, o engajamento nos movimentos de esquerda, suas viagens pela Europa para estudar as novas tendências do teatro europeu, o primeiro encontro com Piscator e Brecht, mestres do teatro épico, e suas visitas à União Soviética. Tais fatores antecedem a composição de Noche de guerra en el Museo del Prado, obra de teatro com a representação do Prado no período da Guerra Civil Espanhola.

Vale lembrar que o teatro foi muito utilizado na Europa pelos movimentos socialistas e operários para fins didáticos, com peças populares para conscientizar os analfabetos ou menos esclarecidos. Assim, Noche de guerra..., inspirada nos estudos de Brecht e Piscator, é uma peça na qual a conscientização política da população espanhola possui grande destaque.

Em 1957, além de voltar à União Soviética, o escritor visitou outros dois países do bloco comunista, como China e Romênia. Em 1963 deixou a Argentina, mudando-se para a Itália, terra de seus antepassados, onde viveu por 14 anos.

\footnotetext{
16 "El mismo Bertold Brecht pretendía montarla en su Berliner Ensemble para conmemorar el vigésimo aniversario del sitio de Madrid durante la guerra civil española. Alberti viajó a Berlín para discutir con el director detalles de la planeada producción pero la muerte de Brecht impidió la realización de este proyecto. Brecht fue quien aconsejó a Alberti la redacción de un prólogo que proveyera el marco externo de la obra." CRISPIN, John. Los tres paraísos: religioso, estético y marxista en Noche de guerra en el Museo del Prado. Insula, Madrid, ${ }^{\circ} 40$ (467), p. 3, oct. de 1985.
} 
Durante esse período, Alberti ganhou diversas premiações, como o Premio Lênin da Paz em 1965, tendo viajado a Moscou para recebê-lo. Foi sua derradeira visita à União Soviética, onde encontrou várias de suas obras traduzidas.

\subsection{O reencontro com o Prado}

Somente em 27 de abril de 1977, pouco depois da morte de Franco e do advento da monarquia parlamentar, Alberti e sua esposa regressaram à Espanha, após praticamente quatro décadas de exílio. Suas primeiras palavras ao descer do avião foram: "Yo me fui con el puño cerrado y vuelvo con la mano abierta en señal de concordia entre todos los españoles"17. E os primeiros lugares que desejou visitar ao retornar à Espanha foram: o Museu do Prado e o Casarão do Bom Retiro.

Ao chegar à Espanha, foi convidado pelo Partido Comunista para se candidatar a deputado por Cádiz, realizando uma singular campanha política por toda Andaluzia. Desta maneira participou das primeiras Cortes Democráticas Espanholas, embora, pouco tempo depois, tenha renunciado para ser "un poeta en la calle":

Por 43.000 votos había logrado un escaño para el Partido Comunista en el Parlamento. Después de cuatro meses, como el poeta en la calle Rafael Alberti no había nacido para parlamentario, con amplio permiso del partido cedió su escaño a un campesino de Trebujena. ${ }^{18}$

Em 1983 Rafael Alberti recebeu o Prêmio Cervantes de Literatura. Este e o Premio Lênin da Paz (1965) foram os mais apreciados por Alberti.

\footnotetext{
${ }^{17}$ ALBERTI, Rafael. La arboleda perdida. Tercero y cuarto libros (1931-1987). Madrid: Alianza, 1998 , p. 253.

${ }^{18}$ Ibidem, p. 258.
} 
Nesse quase um século de vida, estando em sua terra natal ou no exílio, Rafael Alberti sempre esteve ligado aos acontecimentos sócio-políticos e culturais de maior destaque da Espanha. Foi poeta, pintor, dramaturgo, político, historiador de sua época, biógrafo de si próprio em seus cinco autorretratos, chamados de La arboleda perdida, cinco volumes escritos em um longo período de quase 60 anos.

O Porto de Santa Maria se converteu em um lugar de retiro, onde recriou seu passado e escreveu o último volume de La arboleda perdida. Com sua morte em 1999, deixou-nos um valioso e extenso conjunto de obras, dentre as quais, destacamos $A$ la pintura e Noche de guerra en el Museo del Prado, objetos de estudo da presente dissertação.

O Museu se constitui em uma grande fonte de inspiração e relação de Alberti com a Espanha, principalmente durante o longo exílio. Estes dois livros, além de recriarem o Prado e a Espanha, possuem uma grande ligação entre si, pois tratam da relação entre a identidade do escritor, a literatura, a pintura e a História da Espanha. 


\section{A LA PINTURA}

En 1945, año en que terminó la Segunda Guerra Mundial, sentí que me golpeaba fuertemente mi primera vocación, porque sobre todo, la nostalgia del Museo del Prado, en donde había vivido mis más jóvenes años, se me concretó en un libro de poemas titulado $A$ la pintura, que me hizo volver a la experimentación de los colores y la línea, pero esta vez entremezclándolos con la palabra, es decir, con el verso [...] era ya aunque yo no lo pretendiera expresamente, un autor de poesía visiva, que tanto se llegó a cultivar, más que nunca, en la posguerra.

Rafael Alberti 
O livro de poema $A$ la pintura foi publicado pela Editora Losada, em Buenos Aires, no ano de 1948, durante o exílio do escritor Rafael Alberti na Argentina. Na forma deste livro é possível identificar que, após o poema inicial "1917", há uma estrutura triádica, ou seja, a existência de três grupos de poemas: alguns dedicados a cores, outros a pintores e os demais aos elementos da pintura. No entanto, o livro não apresenta esses grupos separados. Esta classificação deve-se à forma e à temática, já que os poemas estão mesclados, alternando-se entre si.

Nas edições de 1953 e 1975 o autor inseriu mais alguns poemas sobre pintores, que completaram a versão definitiva de $A$ la pintura. Todos os trechos desta obra, citados neste capítulo, são baseados na edição de $1989^{19}$.

A seguir serão apresentadas as análises dos poemas da referida obra de Alberti, começando por "1917" e, na sequência, os três grupos.

\section{1."1917"}

O poema "1917" abre o livro como uma introdução. O título refere-se a um ano crucial na vida artística de Alberti, quando se mudou para Madri e conheceu o Museu do Prado, dando início aos estudos de desenho, copiando esculturas clássicas no Casarão do rei Felipe IV - Casarão do Bom Retiro, e aos estudos de pintura nas salas do Prado.

\footnotetext{
${ }^{19}$ ALBERTI, Rafael. A la pintura. (Poema del color y la línea. 1945-1976). Madrid: Alianza, 1989.
} 
O poema divide-se em três partes. A primeira trabalha as recordações das aulas de pintura, realizadas no Museu do Prado no ano de 1917, a segunda refere-se às aulas de desenho nesse mesmo ano no Casarão e a terceira, com versos alexandrinos, sugere o contato de Alberti com as obras do Museu do Prado. A seguir será detalhado o poema.

A primeira parte do poema apresenta referências à vida do poeta -a adolescência, a obsessão pelo ato de pintar, as aulas de pintura nas manhãs do Museu do Prado e a poesia ${ }^{20}$, além do uso da primeira pessoa —-Mi adolescência", "mi equipaje", "Diérame", "me tenía" (p. 9-10), dando ao texto o seu caráter autobiográfico.

Nessa parte, o poema foca-se na paisagem e na pintura: "caja de pintura, / un lienzo en blanco, un caballete" "mi equipaje", "mañana impresionista", "lección abierta de paisaje", "fluye el color de la paleta", "el árbol en violeta", "sombra de morado", "juegan todos los colores", "El bermellón arde dichoso / por desposar al amarillo", "naranja luminoso", "El verde como empalidece", "blanco de plata", "reverdece", "Llueve la luz", "una ninfa fugitiva", "Clarificada azul”, "define el cuadro", "para pintar la Poesia, / con el pincel de la Pintura" (p. 9-10).

À pintura são incorporados novos elementos, partículas oriundas da escrita "Comas" e "puntos" (p. 9), além de reticências a partir da palavra "reticentes". Em paralelo são trabalhados os elementos da natureza — "flores", "hojas", "agua" (p. 9), pois o poema realiza uma comparação entre os elementos da pontuação e a paisagem, em

\footnotetext{
${ }^{20}$ Tanto a palavra "Poesia" como "Pintura" são escritas com letras iniciais maiúsculas por Alberti nos poemas de $A$ la pintura, constituindo uma exaltação dessas artes.
} 
uma tentativa de aproximação entre a pintura e a escritura, dois momentos na vida do artista Alberti.

Além disso, a pintura é associada ao impressionismo—-"mañana impresionista" (p. 9), com o trabalho de luz e água, o que sugere a imagem do líquido, da claridade e do clareamento: "un lienzo en blanco", "Comas radiantes", "y el agua, discos trasparentes", "luminoso", "como empalidece / junto al feliz blanco de plata", "Llueve la luz", "Clarificada azul, la hora / lavadamente se disuelve", "en una atmosfera que envuelve, / define el cuadro y lo evapora" (p. 9-10). Compõe-se, assim, um ambiente de elementos rarefeitos ou fugazes como a atmosfera e o vapor.

À medida que o poema avança no impressionismo, também se acentua o distanciamento temporal, através de um campo semântico de extrema transparência, do etéreo, sugerindo diluição e dissolução. O olhar se impressiona — "que el ojo busca clavar viva" (p. 10), deslumbrado, embora a ninfa escape — "ninfa fugitiva" (p. 10). Por mais que o "eu-lírico" busque resgatar as memórias adolescentes, não consegue alcançar êxito, pois, com o transcorrer do tempo a pintura vai se apagando, evaporando e desintegrando-se para o "eu", tornando-se inapreensível.

No início do poema a imagem que se apresenta é a concreta, com a pintura, no ano específico de 1917, em uma fase específica —a adolescência, com os objetos concretos - "caja de pintura", "lienzo blanco" e "caballete" (p. 9), no ambiente do vigor juvenil — "la locura": 
Com o decorrer do poema, as imagens se tornam cada vez mais claras, diluídas, fugazes - "[...] ya es una ninfa fugitiva / que el ojo busca clavar viva" (p. 10)—e perdem-se. Nos versos próximos ao final os objetos são abstratos - "la ninfa fugitiva" "la hora lavadamente / se disuelve" e "la atmosfera que envuelve, / define el cuadro y lo evapora" (p. 10)-. Nesses versos o único elemento concreto, no caso, o quadro, evapora-se:

Clarificada azul, la hora lavadamente se disuelve en una atmósfera que envuelve, define el cuadro y lo evapora. (p. 10)

O distanciamento temporal também é definido pela diferença entre o momento da enunciação e do enunciado, nítido nos marcadores temporais — "ahora" e "aquel tiempo" (p. 10), nos verbos — "diérame" e "me tenía" (p. 10) - e nos fatos autobiográficos como na contraposição entre a loucura pela pintura naquele tempo e pela poesia de "agora". O poeta busca o passado, a pintura esquecida:

Diérame ahora la locura que en aquel tiempo me tenía, para pintar la Poesía, con el pincel de la Pintura. (p. 10) 
A forma verbal "Diérame" indica pouca possibilidade de realização, ou seja, o "eu" gostaria de que lhe desse a loucura, o ímpeto do passado, o que não ocorreu. Nessa parte do poema é descrita a tentativa de busca da pintura, através das impressões do "eu", do seu deslumbramento em relação aos quadros, com o esplendor de sua luz e suas cores, porém o passado continua inapreensível, já que no final o "eu" fracassa na recuperação da pintura, pois esta permaneceu no passado, encontrando só a poesia presente.

A segunda parte do poema também segue a tendência autobiográfica, o que pode ser comprovado pelo uso de verbos e pronomes na primeira pessoa - "En mi sueño", "Mi mano", "mi ilusión", "mi estado", "nada sabía", "en mi lápiz", "mi sueño prístino", "en mi vida" (p. 10-11), além de fatos que sugerem a vida do artista, como em suas aulas de desenho no Casarão do Bom Retiro e nas referências às memórias juvenis: "Y las estatuas", "En mi sueño / de adolescente", "Mi mano y Venus frente a frente / con mi ilusión de adolescente: / un papel y una carbonilla", "Ante la forma, era mi estado / de pura gracia y de blancura", "Nada sabía del poema / que ya en mi lápiz apuntaba", "mi sueño prístino", "Feliz imagen que en mi vida / dio su más bella luminaria / a esta academia necesaria" (p. 10-11).

As palavras "Y las estatuas" (p. 10) no início dessa segunda parte fazem a conexão ou o elo com a primeira parte, entre os quadros coloridos e as esculturas brancas. Esses versos evocam as estátuas que Alberti estudava nas aulas de desenho: "una Afrodita de escayola / desnuda al ala del diseño", "peregrinante a la ventura, / libre, dichoso y maniatado", "Incontenible, aunque indecisa, / la línea en curva se dispara", "Cautivo al fin que lo promueve", "el claroscuro redondea / la cima exacta del relieve", 
"fingida en yeso, luz y bruma / de carbón, goma y disfumino", "Venus tan sólo dibujaba / mi sueño prístino, suprema" (p. 10-11).

Assim, esta parte do poema foca-se na forma física, no relevo e no volume, compostos com a ajuda da luz e da sombra: "estatuas", "Afrodita de escayola", "Mi mano y Venus", "Ante la forma”, "Incontenible”, "línea en curva”, "pájaro”, "contorno”, "y al negro albor que lo sombrea, / el claroscuro redondea / la cima exacta del relieve", "en yeso, luz y bruma / de carbón, goma y disfumino" (p. 10-11).

Entretanto, ao descrever essas formas, o "eu" não consegue apreendê-las, já que elas escapam, com autonomia e liberdade, desfazendo-se em brisa: "desnuda al ala del diseño", "blancura / peregrinante a la ventura, / libre, dicho", "Incontenible", "la línea en curva se dispara”, "un pájaro", "la brisa” (p. 10).

Com isso, seguem-se a escuridão e a repressão, pois o "eu" encontra-se "maniatado", o que pode aludir tanto à impotência, como à impossibilidade de apreensão. O verso "Cautivo al fin que lo promueve" (p. 11) sugere a idéia de prisioneiro, de refém do próprio desenho:

\footnotetext{
Cautivo al fin que lo promueve

y al negro albor que lo sombrea,

el claroscuro redondea

la cima exacta del relieve (p. 11)
}

Após essa escuridão, são utilizados elementos do mar, como os termos "submarino", "espuma" e "bruma" (p. 11), que indicam a diluição. Em seguida surgem palavras relativas ao desenho, que sugerem a sutileza e rarefação - "luz" e "bruma" (p. 11), atingidas pelo movimento de sombrear ou apagar: "carbón" e "goma" (p. 11). Com 
isso, a forma escurece, dissolve-se e apaga-se, ou seja, desfaz-se a partir de palavras que sugerem o fugaz e o inapreensível, como água, espuma e névoa.

Deste modo, instala-se a tensão entre a ideia de ser desenhista e de ser poeta —_nada sabía del poema / que ya en mi lápiz apuntaba” (p. 11), separadas pela ação do tempo. A distância temporal pode ser comprovada pelos verbos no passado, elementos que também indicam inexperiência e adolescência. As palavras "sueño prístino" (p. 11) apontam uma recordação antiga, distante e primitiva, de se dedicar ao desenho. Ao mesmo tempo, os termos "ya" e "apuntaba" (p. 11) indicam que a poesia já nascia naquele tempo.

Novamente o "eu" vai em busca do passado e, ao invés disso, encontra a poesia presente, o que reforça o distanciamento temporal, contrastando o tempo de narração e o tempo narrado, com o verbo "dar" no passado - "dio" (p. 11) - e o pronome demonstrativo "esta" indicando o presente, ou seja, contrapondo a pintura do passado à poesia presente. O verso "que abre su flor cuando se olvida" (p. 11) indica dois fatos: a experiência necessária para a composição da poesia presente e, ao mesmo tempo, a perda da pintura passada, ou melhor, a criação do presente na perda do passado.

Embora o "eu" busque as estátuas nas memórias, elas se esfumam ou se dissolvem. $\mathrm{O}$ sonho de retomar o ímpeto adolescente e ser desenhista, ao invés de realidade, revela-se uma ilusão: "En mi sueño", "Mi mano y Venus frente a frente / con mi ilusión de adolescente: / un papel y una carbonilla" (p. 10). O "eu" não consegue mais voltar a ter aquela "inocência" juvenil, pois o tempo e a experiência o separam daquela época. 
A terceira parte do poema apresenta a fase adulta do "eu", a partir dos quadros do Museu do Prado. Nesses versos se confirma também o caráter autobiográfico do poema indicado, composto pela predominância da primeira pessoa e as referências à vida do autor no Prado: "Yo tenía / pinares en los ojos y alta mar [...] cuando entré al cielo abierto del Museo del Prado", "como yo creyera", "mi mano tropezaba", "mi adolescencia", "Yo no sabía", "sentí en la sangre mía", "caminé las estancias", "Y comprendí", "y oí", "mis andaluzas", "me ataron", "me azucaró", "penetré al castigo fantasmal", "por mis ojos", "Mis oscuros demonios, mi color del infierno / me los llevó el diablo ratoneril y tierno”, ¿¿Por qué a mi adolescencia las antiguas figuras...?”, "el candor cotidiano de tender los colores / y copiar la paleta de los viejos pintores", "la ilusión de soñarme", "Alberti en los rincones del Museu del Prado", "buscar la Pintura y hallar la Poesía / con la pena enterrada de enterrar el dolor / de nacer un poeta por morirse un pintor", "joh Pintura!, mi amor interrumpido") (p. 11-13).

Os versos apresentam-se no tom da surpresa ou da interjeição, fazendo o uso de exclamações ou interrogações:

¡Oh asombro! !Quién creyera que hasta los españoles
pintaron en la sombra tan claros arreboles;
que de su más siniestra charca luciferina
Goya sacara a chorros la luz más cristalina! (p. 11)

Com a imagem do mar $^{21}$, o "eu" mergulha nos mitos greco-latinos, uma extensão das obras do Museu do Prado: "Mis recatados ojos agrestes y marinos / se hundieron

\footnotetext{
${ }^{21}$ Segundo Salinas de Marichal, "El mar se convierte así en la fuente de juventud en que el poeta va a encontrar el vigor perdido de la creación." SALINAS DE MARICHAL, Solita. Los paraísos perdidos de Rafael Alberti, Insula, Madrid, nº 198, p. 10, mayo de 1963.
} 
en los blancos cuerpos grecolatinos", "Y me bañé de Adonis y Venus juntamente / y del líquido rostro de Narciso en la fuente", "mitología", "aguas italianas" (p. 12). Isso é realizado com a personificação de figuras pintadas ou esculpidas a partir de verbos que indicam movimento: "movieron", "corrieran", "nadaban" e "bailaban" (p. 11-12). Estes sugerem o infinito e a liberdade, na imagem da constelação de estrelas $\longrightarrow$ que representa o Museu - capaz de abrir os horizontes do observador: "cielo abierto" e "ventana abierta" (p. 11).

Entretanto, o "eu-lírico" se questiona porque as antigas figuras da sua adolescência, que eram claras e transparentes, tornaram-se misteriosas e escuras. Após a decepção de descobrir que não conseguiu recuperar a pintura adolescente, as imagens adquirem um tom escuro, negativo, carregadas de palavras que remetem ao diabólico, à desgraça e à escuridão, que vão quase até o final do poema, compondo a visão do inferno: "violentas oquedades / rasgadas por un óseo fulgor de calavera / me ataron a los ímprobos tormentos", "La miseria, el desgarro, la preñez, la fatiga / el tracoma harapiento de la España mendiga", "lo espantoso español más sombrío", "Mis oscuros demonios, mi color del infierno" (p. 12-13).

Para criar esse aspecto sombrio, o "eu" recorre a palavras relativas ao demoníaco e menções a pintores barrocos e alegóricos, como em "penetré al castigado fantasmal verdiseco / de la muerte y la vida subterránea del Greco" (p. 12). Essa parte escura do poema sugere não mais o sonho adolescente, marca da inocência, porém, em seu lugar, alude à experiência da vida adulta, ao fim das ilusões — "la ilusión de soñarme siquiera un olvidado / Alberti en los rincones del Museo del Prado" (p. 13) e ao exílio. 
A partir dos pintores citados nesta parte final é possível traçar uma linha que vai do clássico —Fra Angélico, Mantegna, Rafael, imagem idílica do Renascimento- ao Barroco —Rivera, Murillo, Zurbarán, Velázquez- terminando com os pintores alegóricos flamengos -Patinir, Brueghel, El Bosco- e o próprio Alberti. Os mais escuros-Goya, Bosch e Brueghel— são dimensões do inferno. A ordem cronológica é quebrada com o final reservado aos alegóricos, pintando o demoníaco que o mundo cristão não pintou.

O poema escurece até chegar na morte do pintor e o nascimento do poeta, ou seja, a perda definitiva do passado. Apesar de possuir vários elementos autobiográficos, o nome de Alberti só é mencionado na última estrofe, que é conclusiva. Esses versos finais mostram um Alberti mergulhado na perda de seus sonhos adolescentes de pintor:

[...] la ilusión de soñarme siquiera un olvidado Alberti en los rincones del Museo del Prado; la sorprendente, agónica, desvelada alegría de buscar la Pintura y hallar la Poesía, con la pena enterrada de enterrar el dolor de nacer un poeta por morirse un pintor, hoy distantes me llevan, y en verso remordido, a decirte, joh Pintura!, mi amor interrumpido. (p. 13)

Nos versos finais dessa terceira parte há a aproximação entre o tempo de enunciação e o do enunciado, pois, na medida em que o poema caminha para o final, menos verbos são utilizados no tempo passado, - "hoy distantes me llevan, y en verso remordido, / a decirte, joh Pintura!, mi amor interrumpido" (p. 13) - e a pintura é perdida. Aqui os versos estão mergulhados na dor, no inferno e na miséria humana do mundo adulto, que se define na relação entre a pintura e a poesia. A partir do horror 
nas memórias deformadas pelo tempo, a pintura primeira é descrita com o seu amor interrompido, ou seja, termina a busca da beleza em suas impressões juvenis e o "eu" encontra em seu lugar a poesia da vida adulta.

O poema "1917" é um movimento de evocação. A voz lírica está situada nas lembranças de uma época: 1917. É um rememorar a partir da intimidade da primeira pessoa. $O$ tom da primeira e da segunda parte é o da evocação, uma tentativa de resgatar o universo da inocência, lócus inicial do poema.

As duas primeiras partes mostram as aulas de pintura e desenho, através do seu deslumbramento. Nesses versos é evocada a expectativa adolescente, na imagem da felicidade e inocência e no desejo de pintar e desenhar. No entanto, o "eu" está vendo essas duas primeiras partes à distância, pois há uma diferença entre o tempo da enunciação e do enunciado. Na primeira parte ocorre a busca da pintura, trabalhando as cores e seu contexto na paisagem; na segunda há a busca pela escultura e pelo desenho, trabalhando o mundo das formas, dos relevos, do jogo entre o claro e o escuro. Da primeira para a segunda parte há apenas a mudança semântica, pois passa da pintura para o desenho. Já da segunda parte para a terceira, além da mudança de campo semântico, pois passa do desenho para o poema, há também alteração na forma: os versos passam a ser alexandrinos e o tom da evocação é substituído pela interjeição. Nesta fase final, o poema mergulha nos quadros do Prado.

A densidade que o poema vai ganhando decorre da passagem do tempo. $O$ ano de 1917 foi distorcido pela distância temporal. A estrofe final de cada parte traz a perda do passado, lembrando que o livro foi escrito décadas depois, no exílio na Argentina, entre 1945 e 1948. 
A menção direta ao Prado só aparece na terceira parte do poema, com o assombro a partir da exclamação, mudando o tom da evocação para a interjeição, no lócus da experiência. Agora, para o "eu", a pintura está perdida: "en mi sueño / de adolescente", "mi amor interrompido" (p. 10-13). O "eu-lírico" fala de seu amor interrompido para aludir à fratura de sua própria vida, já que ele também foi separado da pintura do Prado. Ao buscar a pintura, nasce o poeta adulto.

Assim, as três partes do poema podem indicar as duas fases da vida do artista: a do jovem pintor e desenhista, na inocência, e a do poeta adulto, na experiência. A construção da representação do Prado se dá pelo movimento do "eu" do passado ao presente, como um passeio pela pintura e pelo Prado, por meio da memória, representando sua formação. O poema é uma síntese da trajetória do "eu-lírico", da inocência à maturidade.

\subsection{Poemas sobre cores}

O livro A la pintura (1948) dedica poemas a seis cores: o azul, o vermelho, o amarelo, o verde, o negro e o branco.

O poema "Azul" explora a cor e suas nuances na natureza e na pintura, elaborando esta que foi a última cor a ser dominada e reproduzida pelo homem e, por sua nobreza, plenamente utilizada no renascimento nos países mediterrâneos. 
A cor azul, na maioria das vezes no poema, está relacionada ao mar², ao céu, às paisagens, aos pintores e às pinturas mediterrâneas ${ }^{23}$ : da beleza de Vênus de Botticelli à pureza da Virgem em Fra Angélico, como se pode observar nos primeiros versos, que apresentam o azul:

\author{
1 \\ Llegó el azul. Y se pintó su tiempo. \\ 2 \\ ¿Cuántos azules dio el Mediterráneo? \\ 3 \\ Venus, madre del mar de los azules. \\ 4 \\ El azul de los griegos \\ descansa, como un dios, sobre columnas. \\ 5 \\ El azul Edad Media delicado. \\ 6 \\ Trajo su virginal azul la Virgen: \\ azul María, azul Nuestra Señora. (p.26)
}

Para o "eu", o azul pintou o seu tempo, destacando-se principalmente no renascimento, simbolizado pela Vênus de Botticelli. Entretanto, não se restringe a este movimento artístico, pois a cor está relacionada também à região, como se pode comprovar nas citações dos seguintes espaços: Grécia, França, Espanha e Itália, ou seja, o mediterrâneo.

\footnotetext{
${ }^{22}$ Segundo Zardoya, o elemento mar em Alberti é um constante vínculo com a pátria em muitos de seus poemas do exílio. ZARDOYA, Concha. Poesía y exilio de Alberti. Cuadernos Hispanoamericanos, Madrid, nº 485-486, p. 168, nov./dic. de 1990.

${ }^{23}$ De acordo com García Terrés, para Alberti, o mar representa Cádiz e a mitologia greco-latina. GARCIA TERRÉS, Jaime. El mar y la mar de Rafael Alberti. Occidente, Madrid, nº 109, p. 88, jun. de 1990.
} 
No decorrer do poema são apresentados pintores que se destacaram no uso da cor azul na história da pintura segundo a visão do "eu". São citados em ordem quase cronológica os seguintes pintores: Fra Angélico ${ }^{24}$, Rafael ${ }^{25}$, Perugino ${ }^{26}$, Tiziano ${ }^{27}$, Poussin $^{28}$, Tintoretto ${ }^{29}$, El Greco ${ }^{30}$, Velásquez $^{31}$, Rubens $^{32}$, Patinir $^{33}$, Murillo $^{34}$, Tiépolo ${ }^{35}$, Goya $^{36}$, Manet ${ }^{37}$, Renoir ${ }^{38}$ e Picasso ${ }^{39}$, tentando transpor para a linguagem poética os detalhes da tonalidade utilizada por cada pintor.

Na hora de se definir, o azul apresenta-se como o pintor espanhol Velázquez e, ao final, também em primeira pessoa, transforma-se em Pablo Picasso, uma alusão a sua fase azul:

Dijo el azul un día:

- Hoy tengo un nuevo nombre. Se me llama:

Azul Pablo Ruiz, Azul Picasso. (p. 30)

\footnotetext{
${ }^{24}$ Fra Guido di Pietro Muguello Angelico (1395/1400-1455), pintor italiano do século XV, de várias influências, conhecido na Espanha como Fra Angélico.

${ }^{25}$ Rafael Sanzio (1483-1520), pintor renascentista italiano, conhecido como Rafael.

${ }^{26}$ Pietro di Cristoforo Vanucci (1450-1523), pintor renascentista italiano que participou da pintura da Capela Sistina, conhecido como Pietro Perugino.

${ }^{27}$ Tiziano Vecellio di Gregorio (1489-1576), pintor italiano e o principal artista veneziano do renascimento.

${ }^{28}$ Nicolas Poussin (1594 - 1665), pintor clássico francês, que obteve êxito em Roma.

${ }^{29}$ Domenico Tintoretto (1560-1635), pintor renascentista veneziano.

${ }^{30}$ Doménikos Theotokópoulos (1541-1614), pintor, escultor e arquiteto grego, mais conhecido como El Greco. De estilo maneirista, desenvolveu a maior parte da sua carreira na Espanha.

${ }^{31}$ Diego Rodríguez de Silva y Velázquez (1599-1660), pintor maneirista espanhol, responsável por diversos retratos da corte espanhola como Las meninas de 1656.

${ }^{32}$ Peter Paul Rubens (1577-1640), o pintor barroco mais popular da escola flamenga. Na Espanha é conhecido como Pedro Pablo Rubens.

${ }^{33}$ Joachim Patinir (1480-1524), pintor renascentista flamengo, especializado em motivos históricos e paisagens.

${ }^{34}$ Bartolomé Esteban Murillo (1617-1682), pintor barroco espanhol.

${ }^{35}$ Giambattista Tiepolo (1696-1770), pintor italiano, de estilo rococó, conhecido como Giovanni Battista Tiepolo.

${ }^{36}$ Francisco José de Goya y Lucientes (1746-1828), pintor espanhol dos séculos XVIII e XIX. Suas obras incluem uma grande variedade de retratos, paisagens, cenas mitológicas e demoníacas.

${ }^{37}$ Édouard Manet (1832-1883), pintor francês impressionista e naturalista.

${ }^{38}$ Pierre-Auguste Renoir (1841-1919), pintor francês impressionista.

${ }^{39}$ Pablo Ruiz Picasso (1881-1973), pintor, escultor e desenhista espanhol do século XX.
} 
O azul neste poema está sempre associado ao mediterrâneo, tanto em relação à paisagem, normalmente $0 \operatorname{mar}^{40}$, como em relação à pintura, uma segunda natureza. Mesmo quando indica o céu, refere-se às pinturas clássicas dos tetos das capelas italianas.

O poema "Rojo" explora o vermelho e suas nuances na natureza e na pintura, fundindo tonalidades, quadros e pintores. Inicia-se com a cor em primeira pessoa apresentando-se como natureza nas imagens de coloração vermelha intensa, como o nascer e o pôr do sol.

Tanto o vermelho do amanhecer, como o do anoitecer sugerem a passagem do tempo, já que o sol é um indicador temporal. O decorrer do tempo também é marcado na referência à fruta — "Lucho en el verde de la fruta y venzo" (p. 44), que indica a vitória do vermelho sobre o verde no processo de amadurecimento.

Além da relação natureza e tempo, o poema introduz o homem e, com este, o vermelho personificado em sentimentos como raiva, cólera, ira e excitação, substantivos abstratos que indicam o caráter muitas vezes intenso ou explosivo na humanidade. O vermelho apresenta-se também como cor púrpura, no consumo de vinho, associado aos copos, às taças e às garrafas de bebidas, evocando a imagem de Baco. Em comum, vermelho e púrpuro simbolizam o aumento da pressão sanguínea,

\footnotetext{
${ }^{40}$ Segundo Salinas de Marichal, "En el primer momento, el del primer libro, Alberti está en la actitud del hombre que ha perdido el paraíso infantil y su paisaje, el mar [...] el paraíso es un huerto perdido, hundido en lo profundo del mar. Es un mundo submarino situado en un más allá que está bajo el terrestre. Sorprende esta búsqueda del paraíso hacia abajo puesto que en general los soñadores de paraísos buscan hacia arriba, hacia los cielos." SALINAS DE MARICHAL, Solita. Los paraísos perdidos de Rafael Alberti, Insula, Madrid, nº 198, p. 4, mayo de 1963.
} 
estendendo-se ao retrato da sensualidade, como na imagem mitológica de Vênus, representada pelo quadro Vênus adormecida, do pintor Giorgione ${ }^{41}$ :

Rojo en el lábio y menos

en las pequeñas cumbres

donde gustosamente

Venus ganando pierde las batallas. (p. 45)

$\mathrm{Na}$ composição dos temas humanos o poema também recorre a Flandes $^{42} \mathrm{e}$ Rubens, pintores da escola flamenga. O primeiro é um pintor renascentista de temas religiosos cristãos e o segundo é o pintor barroco que enfatizava as cores em movimento, associadas à sensualidade e à orgia. Assim, o poema vai do sagrado ao profano, construções humanas extremas, sem suprimir a miséria humana, que está retratada no acervo do Museu do Prado por Brueguel e Bosch $^{43}$, autores de quadros sobre a escuridão e o inferno, além do anjo "Luzbel" ${ }^{44}$ ardendo em fogo, representando o demoníaco.

Por outro lado, a mistura das tintas e a miscelânea de colorações também ganham destaque, com o "eu" convidando as outras cores a fazerem parte da produção artística - “Ven, amarillo. Quiero ser naranja” (p. 46), retratando o universo da pintura a partir de Velázquez, passando por Goya, Renoir, Rosales, até Picasso.

\footnotetext{
${ }^{41}$ Giorgio Barbarelli da Castelfranco (1477-1510), pintor renascentista veneziano que introduziu um novo uso para a paisagem, o de moldura para a deusa. É conhecido como Giorgione.

${ }_{42}$ Juan de Flandes (1465-1519), pintor renascentista conhecido como Juan Flamenco. Trabalhou na Espanha a serviço de Isabel, a Católica.

${ }^{43}$ Pieter Brueghel (1525/1530-1569), pintor flamengo conhecido como Brueghel, "o velho", para distingui-lo de seu filho de mesmo nome. Foi influenciado pelo pintor El Bosco, em particular no início dos estudos de imagens demoníacas, como o "Triunfo da morte" e "Dulle griet".

44 "Luzbel" ou Lúcifer — do latim Lux fero, o portador da Luz, o mais forte e o mais belo de todos os Querubins tornou-se orgulhoso, não aceitando mais servir a Deus. Sendo assim, os anjos leais a Deus o derrotaram e o expulsaram do céu, juntamente com seus seguidores. Desde então, o mundo vive esta guerra eterna entre Deus e o Diabo, este personificado em Lúcifer. As mais comuns associações a esta figura são o elemento fogo, o calor e a cor vermelha.
} 
No tema pictórico, várias imagens são evocadas, desde a do elemento cádmio ${ }^{45}$, associado tanto à pintura, como à destruição, aqui representadas pela diluição de cores em Goya, que pintou a miséria humana, a guerra e a destruição na Espanha, como também a imagem inversa, da beleza na vida representada pela cor rosa. Esta pode ser vista tanto na fase rosa de Renoir — "Me vertí en rosa — Renoir- y puse / un nuevo nombre -Renoir - al mio" (p. 47)— ou de Picasso — "Bajé hasta el rosa rosa de Picasso" (p. 47), ou ainda no rosa da inocência, na angelical menina em Rosales — "La niña rosa —ioh sueño! — de Rosales" (p. 47), referência ao quadro La condesa de Santovenia, conhecido também como La niña rosa ou La niña de rosa, do madrileno Eduardo Rosales ${ }^{46}$, no qual a garota possui tanto a face rosa, como também o vestido dessa cor.

Vale ressaltar que os versos sobre a mistura de tintas e cores associam-se aos quadros e pintores mais representativos do Museu do Prado, com a predominância da escola espanhola. Aliás, é somente nessa parte do poema que são citados os pintores da Espanha: Velázquez, Goya, Rosales e Picasso.

Em complemento a isso, também são retratados os símbolos da Espanha, pois nos versos finais o poema entra no intenso vermelho do sangue nas arenas de touros e nos movimentos da tourada, do toureiro e da dançarina de flamenco. Assim, o vermelho relaciona-se à terra e à bravura, "en las arenas" (p. 48) de touros, locais de combate ou luta, imagem completada pelo "rojo español redondo de las plazas" (p. 48), alundindo ao formato das arenas. A composição deste formato é reforçada pela assonância da

\footnotetext{
${ }^{45}$ Cádmio é um metal pesado, componente de pilhas e baterias químicas, associado ao mercúrio e ao zinco, muito tóxico e perigoso para a saúde humana, de pigmentação brilhante, característica ressaltada pelo adjetivo "lustroso".

${ }^{46}$ Eduardo Rosales (1836-1873), pintor espanhol do séc. XIX. Seu estilo maduro se forma através de sua interpretação pessoal dos mitos pictóricos do seu tempo, até alcançar una plástica completamente moderna em sua obra-prima, La condesa de Santovenia ou La niña rosa (1871, Prado).
} 
vogal /o/ em "r[o]j[o] españ[o]l red[o]nd[o] de las plazas", que sugere o caráter circular, redondo das arenas. Além da cor do relâmpago — "Rojo como el relámpago / espiral de una alegre revolera" (p. 48), ele é associado à palavra "espiral", sugerindo, assim, os giros do capote do toureiro, já que este costuma ser de coloração vermelha, chamado de "capa revolera", realiza giros e possui a rapidez sugerida pelo relâmpago para driblar o touro ${ }^{47}$.

Esta aproximação entre o vermelho e a Espanha também se faz através do cravo — "Como el clavel que estalla en los ceñidos / marfiles de unos senos apretados" ( $p$. 48), que sugere a imagem da dançarina de flamenco ou a mulher na Espanha, pois essa é a flor que as dançarinas utilizam nessa dança e que as espanholas lançam aos toureiros ao final da tourada.

Além disso, outras imagens que sugerem a Espanha são construídas, como o vermelho das plantações floridas espanholas de amapola e o recife de corais, que se associa ao mar: - "Bañado por el mar y trabajado / por su garganta azul, florezco y subo / fino ramo encendido de corales" (p. 48).

Nos versos finais —-"Pensad que ando perdido en la más mínima, / humilde violeta" (p. 48) - há também a presença do plural, "vosotros", que é exclusivo da variante peninsular da língua espanhola, para demonstrar proximidade e intimidade em uma conversa do "eu-lírico" com os leitores. Nesses versos o verbo auxiliar "ando" indica continuidade do fato de estar perdido e o uso do imperativo "Pensad" funciona como um vocativo para chamar a atenção do leitor.

${ }^{47}$ No exílio, o touro é um elemento consolador na poesia de Alberti. De acordo com García Montero, "Inmediatamente se identifica al pueblo español con la fiereza noble del toro. La fuerza mitológica de este animal nacionalizado, su destino de pelea, su nobleza y la derrota final en los ruedos encarnan perfectamente la historia del pueblo español, dejando siempre la posibilidad abierta para un retorno de lucha, para el resurgimiento de una cornada vengativa." GARCIA MONTERO, Luis. Alberti, Poeta del exilio. Cuadernos Hispanoamericanos, Madrid, nº 485486, p.183, nov./dic. de 1990. 
Neste poema, a cor vermelha corporifica a Espanha e ganha expressividade, pois consegue evocar a pátria, estando presente na pintura, no homem, nos pintores e nos quadros do Museu do Prado.

O poema "Amarillo" explora a cor amarela e suas nuances na vida, na morte, na natureza e na pintura. Esta cor surge com a luz e a sombra - "Acciono con la luz, soy un activo / cómplice de la luz contra la sombra." (p. 59), sugerindo o volume desde os versos iniciais.

Neste poema a morte é dissecada:

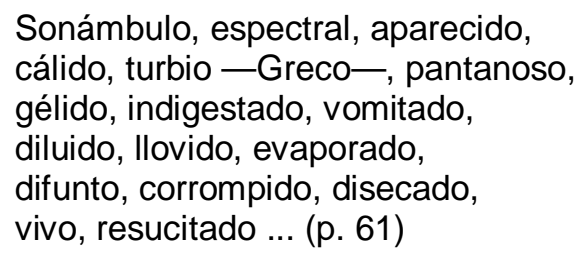

No entanto, tal morte não é definida de forma estática, e sim em trânsito, no movimento da vida à morte: "...Mas tengo el privilegio de ser verde / y desnudarme otoño- en amarillo" e "Hueso amarillo en polvo, desvelado / resplandor de la muerte en movimiento" (p. 59 e 62). Esses dois versos possuem a aliteração das consoantes contínuas, /s/, /m/, /n/, ///, /II/, e /v/, que sugerem movimento, completado pelo uso da própria palavra "movimiento": "Hue[s]o a[m]ari[II]o e[n] po[l][v]o, des[v]e[l]ado / resp[l]a[n]dor de la [m]uerte en [m]o[v]i[m]ie[n]to."

O "Amarillo" mostra os extremos, indo da vida, com o contorno e o volume, à pulverização do corpo humano, com a falta desse volume na morte, ou seja, o trânsito 
entre a vida e a morte, como nos seguintes versos: "Me amaso con la luz, y con el rosa / de la carne me fundo y permanezco" (p. 61).

Além disso, a cor amarela move-se do ouro ao osso: "Oro en el nimbo de los viejos santos. / Oro ingenuo labrado de Edad Media", "El pálido amarillo de la muerte", "Marfil oculto dentro de la carne" (p. 60-61).

Em paralelo, a cor percorre outro movimento, que é o ciclo da alegria à tristeza e novamente à alegria: "Feliz, risueño, alegre, delicado / —Goethe, en estado puro", "Soy la cera, la lágrima / caliente por el cuello de los cirios" e "Cuando rompo a volar y mi garganta [...] suelta un oro de flautas repetidas, / le dan a mi alegría un amarillo [...]" (p. 59-63).

Na mesma linha, a natureza também se apresenta em plena transformação: como natureza primeira e viva - “...Mas tengo el privilegio de ser verde / y desnudarme —otoño— en amarillo", "A ti, elevado a pura trasparencia, / tenue, amarillo aéreo de la rosa", como segunda natureza, na pintura — "Senos áureos, espaldas / —Tiziano— como finas / rodelas de oro puro"- e como natureza morta: "Un ordenado esférico amarillo / naturaleza muerta" (p. 59-64).

Esse trânsito do amarelo também pode ser demonstrado a partir das mudanças cromáticas assumidas por ele no decorrer do poema: “...Mas tengo el privilegio de ser verde / y desnudarme —otoño— en amarillo", "Me amaso con la luz, y con el rosa / de la carne me fundo y permanezco", "Temo el azul porque me pone verde", "Me tuesta el ocre. El rojo / me excita y me suspende hasta la altura / naranja de la llama", "El amarillo cromo, satinado" (p. 59-63). 
A assonância da vogal brilhante /a/ e a aliteração das sibilantes /s/ e /c/ nesses versos sugerem a imagem da chama, do fogo, de cor laranja: "me ex[c]it[a] y me [s]u[s]pende h[a][s]t[a] I[a] [a]Itur[a] / n[a]r[a]nj[a] de I[a] I[a]m[a]"

Além das cores, o poema também transita pela História da Pintura, citando em ordem cronológica os pintores Tiziano, Veronés ${ }^{48}$, El Greco, Rembrandt ${ }^{49}$, Zurbarán ${ }^{50}$, Goya e Van Gogh ${ }^{51}$, ordem adotada tanto pelo Museu do Prado como também, muitas vezes, por Rafael Alberti.

Neste caminhar, desde o surgimento do amarelo, na luz contra a sombra e nas descrições dos contornos, cores, misturas e tonalidades, o poema também sugere o efêmero, a brevidade e o trancorrer da vida, transmutação que é simbolizada pelas várias tonalidades do amarelo, em direção à morte e à posterior imortalidade artística através da pintura, representada pela submissão às leis geométricas.

Desta forma, o "Amarillo" mostra o trânsito da vida em três fases: na primeira apresenta a vida, acionada pela luz, nos versos iniciais; na segunda fase, a imagem da morte, da vela e da lágrima e, na terceira, a imortalidade através da pintura, tratando das cores, quadros e pintores, terminando no arco-íris e nas leis geométricas.

Após passar por várias transformações cromáticas, o amarelo retorna ao seu estado inicial, original, puro, na estrofe final, apresentando o ciclo da vida, ou seja, dando ao poema o movimento cíclico. Assim, a cor amarela representa a vida, que só existe em seu próprio transcorrer, no trânsito por suas diversas fases.

\footnotetext{
${ }^{48}$ Paolo Caliari (1528-1588), pintor renascentista italiano, conhecido na Espanha como Pablo Veronés, um dos maiores mestres da pintura veneziana.

${ }^{49}$ Rembrandt Harmensz Van Ryn (1606-1669), o pintor holandês mais importante do século XVII, especialista em temas religiosos e mitológicos, conhecido como Rembrandt.

${ }^{50}$ Francisco de Zurbarán (1598-1664), pintor maneirista español.

${ }^{51}$ Vincent Willem Van Gogh (1853-1890), pintor pós-impressionista holandês.
} 
O poema "Verde" explora esta cor e suas nuances na natureza e na pintura. Assim, o verde é associado ao azul do mar — "yo soy el verdemar" (p. 73), à primavera —“Tengo otro nombre: Primavera" (p. 73) - e às plantas: "copa, que los árboles", "la hoja", "tallo", "ojival" e "olivo" (p. 73-74).

Como tinta, o verde se mistura a outras cores, como o azul — "Yo soy el verdemar, / subido a azul cuando el azul del cielo", "A veces me acelesto y me confundo I con el azul que anhela erguirse verde" (p. 73-75) - e o amarelo — "Aunque soy verde, tengo / muchas veces el alma de amarillo" (p. 75), que são as cores primárias para produzir o verde, além do negro e azul, utilizados para escurecê-lo: "Cuando sueño ser gris le quito un poco / al negro y al azul de su hermosura" (p. 75).

Desse modo, o poema explora o verde na pintura, nos quadros de pintores famosos: "El alegre, bailable, florecido / verde —Brueguel— flamenco", "Para Tiziano, un jubiloso, eterno / verde ondear de tréboles floridos", "Me han dado un nombre Veronés - que tiene / blasón de principado", "El mar vomita un verde umbroso alga [...] la tenebrosa luz que empuja al Tintoretto", "Un agónico verde helado Greco, / un verde musgo legamoso Greco [...] un verde roto Greco", "Verde jubón en un arcabucero / — Velázquez—de 'Las lanzas”, "Voz de verde misterio / —Rembrandt”, "Para Rubens, un rubio verde viña", "Un verde popular de romería / y un lazo en fino verde para Goya", "Delacroix ${ }^{52}$ me exalta hasta dar voces", "Courbet ${ }^{53}$ —verde intrincado de selva - me ensombrece", "Cézanne ${ }^{54}$ me corta, Renoir me envuelve" (p. 75-77). Ao final das

\footnotetext{
52 Ferdinand Victor Eugène Delacroix (1798-1863), pintor romântico francês, especialista em sublimar os sentimentos por meio da cor.

${ }^{53}$ Gustavo Courbet (1819-1877), pintor realista francês.

${ }^{54}$ Paul Cézanne (1839-1906), pintor pós-impressionista francês e elo para o cubismo do século XX.
} 
citações, o poema recorre aos impressionistas: "verde Francia / (Manet, Sisley ${ }^{55}$, Monet $^{56}$, / Pissarro ${ }^{57}$, Renoir...)" (p. 77).

Por outro lado, o verde também se apresenta como primeira natureza, a partir do elemento água, ou melhor, na figura do mar que separa o "eu" da terra natal:

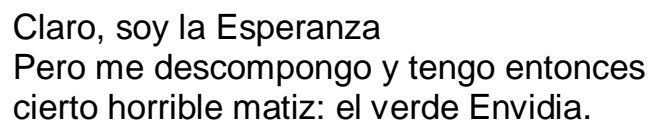

Essa natureza representa a juventude perdida do "eu", a partir de seu fracasso na busca do passado, pois, embora se defina em primeira pessoa como Esperança, o verde decompõe-se em inveja com o mergulho no tempo e a perda do passado.

Desta forma, os versos "Y tierra verde antiguo en los pinceles / de las manos maestras ya remotas" (p. 74) evocam a terra natal, projetada nos verdes dos mestres do "eu", pintores das obras que compõem o Museu do Prado.

Assim, no desfecho final o "eu-lírico" confirma o seu fracasso, pois não consegue captar a luz: "En la sombra persisto. / En la luz arrebato y borro todo". O uso de "un día", "en ciertos momentáneos", acompanhados do condicional "si [...] pudiera" (p. 78) indica uma hipótese irreal ou de improvável realização. O desejo de fundir os pincéis que estão separados pelo mar fica restrito à imaginação, nas memórias "Desagradables verdes que dan gritos / en pinceles que nadie ve ni escucha" (p. 78), o

\footnotetext{
${ }^{55}$ Alfred Sisley (1839-1899), pintor impressionista francês com nacionalidade britânica.

${ }^{56}$ Oscar-Claude Monet (1840-1926), pintor impressionista francês.

${ }^{57}$ Jacob Camille Pissarro (1830-1903), pintor impressionista francês.
} 
que revela a solidão: "un verde, el más hermoso / de los verdes, que olvido o no recuerdo" (p. 78).

Neste poema o verde associa-se à natureza e à pintura, que representam a juventude do "eu", fase da vida interrompida não só pela passagem do tempo e pela maturidade, mas principalmente pelo exílio do pintor na Argentina, do outro lado do mar.

O poema "Negro" explora a diversidade dessa cor na pintura, começando com o revés da luz, em comparação ao branco, e a exaltação do seu surgimento: "Dio su revés la luz. Y nació el negro" (p. 97). A partir de um buraco na luz, o negro entra em cena para defender a sua beleza: "Y abrió un hoyo en lo claro, un agujero / desde el que dijo: -Soy también hermoso" (p. 97).

Se no poema seguinte o branco será a tela que receberá a pintura, neste o negro é o traço que dá forma aos contornos do desenho: "Negro como la tinta, negro como / la que linea el cuerpo del dibujo, / la que muerde la sombra del grabado" (p. 97). O negro é apresentado como antiface ou a face inversa do branco, porém necessário: “¿Qué sería del fuego sin ti, qué de la lumbre / sin el negro carbón que la sustenta?" (p. 101).

Neste poema, tanto em relação à escola flamenga —-Durero ${ }^{58}$ e Rembrandtcomo em relação à espanhola -El Greco, Carreño ${ }^{59}$ e Goya, o negro se mostra como negativo, triste, obscuro, associado à dor e à morte. Entretanto, nem toda pintura em que predomina a cor negra necessita ser assim, negativa. É preciso olhar para as

\footnotetext{
${ }^{58}$ Albrecht Dürer (1471-1528), o mais importante pintor do renascimento alemão, com uma formação no mundo gótico flamengo, que influenciou os artistas na Alemanha e nos Países Baixos, conhecido na Espanha como Alberto Durero.

59 Juan Carreño de Miranda (1614-1685), pintor barroco espanhol do século XVII, que se destacou na Corte Espanhola de Felipe IV e Carlos II como retratista.
} 
pinturas estrangeiras para observar a beleza da cor negra, principalmente a pintura italiana, que mostra a alegria e a beleza do negro, defendidas pela própria cor desde os primeiros versos - "-Soy también hermoso" (p. 97), mostrando que a luz e o negro não são excludentes:

Quisieron rehuirme, pensando que la luz me rechazaba.

Pero soy tan hermoso, que llamado por ella a mí volvieron. (p. 101)

Há também o meio termo, em imagens nas quais o negro não se apresenta alegre nem triste, como no caso do "impotente [...] negro del Greco" e de "levanté impotente monarquia / en la mano tranquila de Velásquez" (p. 99), ao retratar a monarquia, ou no "negro negro" (p. 100) do mexicano Rivera ${ }^{60}$.

O poema mescla o negro da alegria e da beleza, presente nos italianos Tiziano e Tintoretto, com o da tristeza e da morte de alguns pintores flamengos e espanhóis. $\mathrm{O}$ negro dos românticos é associado ao pesadelo, já o dos alemães é apresentado como melancolia. Depois de Tintoretto, por exemplo, o poema cai na tormenta, para anunciar o negro da Espanha. E no final, foca-se na imagem positiva dessa cor, com as belezas do negro evaporado do impressionista Manet e a pureza do negro nas pinturas dos fundadores do cubismo, os pintores Juan Gris ${ }^{61}$ Braque $^{62}$ e Picasso.

\footnotetext{
${ }^{60}$ Diego María Rivera (1886-1957), muralista mexicano.

${ }^{61}$ José Victoriano González-Pérez (1887-1927), pintor español cubista, conhecido artísticamente como Juan Gris.

${ }^{62}$ Georges Braque (1882-1963), pintor e escultor cubista francês.
} 
No poema "Negro", a cor não se apresenta na forma convencional, porém com dupla face. Não é apenas o complemento dialético do branco, como negativo, triste e pesado, mas adquire qualidades próprias, podendo ser também positivo, alegre e criativo.

O poema "Blanco" explora as funções dessa cor nas paisagens e na pintura, exaltando em primeira pessoa sua onipresença e seu poder, sendo imprescindível à pintura -"Dijo el blanco: - Yo puedo, / feliz, estar en todo, porque soy / la imprescindible sangre [...]" (p. 116), como base, fundo branco ou luz capaz de clarear as demais cores.

A cor branca é associada a elementos bem diversificados, relativos tanto à humanidade —colunas, paredes, ilha de Creta, papel, cal, muros andaluzes, populares, a cidade de Cádiz, giz, toalha de mesa, lenço, fio, lençol, touca, gargantilha e monge, como também à natureza: neve, dia, nuvem, pássaro, espuma do mar, pomba, fantasma e marfim.

Isso aponta que o branco é acessado a partir das lembranças do "eu", já que essas imagens associam-se às particularidades de sua infância na cidade de "Cádiz", onde predomina esta cor, o que Ihe dá um caráter autobiográfico, reforçado na menção do nome Rafael Alberti:

Blanco como la nieve, blanco como el papel, blanco blanco como la cal al sol de los tranquilos muros andaluces. 
Yo vi -Rafael Alberti-

la luz entre los blancos populares.

7

Mi infancia fue un rectángulo

de cal fresca, de viva

cal con mi alegre solitaria sombra.

8

Blanco Cádiz de plata en el recuerdo

9

Yo soy el hijo de la cal más pura.

10

Temo al negro. Me teme

el negro a mí. La noche

tiene miedo del día.

El día, de la noche. (p. 116-117)

A partir de ser mencionado o nome do autor Rafael Alberti, a pintura desenvolvese e os pintores que se destacaram com a cor branca são citados no poema, como o Fra Angélico, Ucello ${ }^{63}$, Piero della Francesca ${ }^{64}$, Brueghel, El Greco, Zurbarán, chegando no auge do uso do branco na produção artística com os impressionistas franceses:

Soleo, aclaro, enturbio, diluyo, trasparento, lavo, esfumo, evaporo (Manet, Sisley, Monet,

Pissarro, Renoir...) (p. 120)

\footnotetext{
${ }^{63}$ Paolo Uccello (1397-1475), pintor renascentista italiano.

${ }^{64}$ Piero Della Francesca (1415-1492), pintor e matemático renascentista italiano.
} 
Vale lembrar que esses dois últimos versos acima, que citam os pintores, são exatamente idênticos aos versos do poema "Verde" que descrevem o verde da França.

Ao final, de forma cíclica o poema retoma as imagens iniciais, de fundo branco, base para a pintura —-Blanco puro, total, más prisionero / en un cuadrado, un círculo, un triángulo" (p. 121), e da natureza: "Recordad que también yo soy la rosa." (p. 121)

Este é o sexto e último poema sobre as cores, além de ser o único a citar diretamente o nome do autor Rafael Alberti em seus versos. Nele, o branco, como base para a pintura, recorre à natureza, às paisagens mediterrâneas e andaluzas, às recordações do "eu" que desencadeiam as referências aos pintores que se destacam no trabalho com a cor branca.

Neste poema, o branco representa não apenas o fundo, como plataforma para a pintura, mas se estende também como base para as memórias do poeta, ou seja, adquire um valor autobiográfico.

Embora esses seis poemas possuam algumas características em comum, como o uso de versos livres, enjambement, além de estrofes como unidades independentes, cada um explora sua cor na natureza, na pintura e em outros meios, de acordo com suas particularidades na visão do "eu", que faz uso de menções a pintores, de descrições visuais e espaciais, além de citar colorações, misturas e nuances.

Os pintores mencionados, em sua maioria, são da coleção do Museu do Prado, chegando em alguns versos a mesclar os nomes dos pintores com os das cores. No poema "Azul", por ejemplo: "Lo bautizaron con azul los ángeles. / Le pusieron: Beato Azul Angélico" (p. 27) e "Dijo el azul un día: / —Hoy tengo un nuevo nombre. Se me Ilama: / Azul Pablo Ruiz, Azul Picasso" (p. 30); no poema "Rojo": "Me vertí en rosa — 
Renoir- y puse / un nuevo nombre —Renoir- al mío" (p. 47) e no "Blanco": "—Dame la gracia / de a Fray Añil volverlo más angélico / y de empalidecer aún más el rosa" (p.118).

Além disso, as pinturas e os pintores citados muitas vezes são apresentados em grupos, por países e épocas, como escolas, do modo como o Museu do Prado divide a sua coleção, como no poema azul, por exemplo:

Los azules de Italia, los azules de España, los azules de Francia... (p. 27)

No poema "Verde":

A ti, verde lavado, líquido verde Francia (Manet, Sisley, Monet, Pissarro, Renoir...) (p. 77)

No poema "Negro": "Negros de Italia, negros / con un rumor de pinos soleados" (p. 98) e "Negro de España" (p. 99)

No poema "Blanco":

Soleo, aclaro, enturbio, diluyo, trasparento, lavo, esfumo, evaporo (Manet, Sisley, Monet, Pissarro, Renoir...) (p. 120) 
Outra característica peculiar desses poemas ${ }^{65}$ é a personificação das cores, sendo comum neste livro elas se expressarem em primeira pessoa, dizendo quem são e a que vêm, principalmente nos versos iniciais.

A estrutura dos poemas é composta a partir de narrações das cores na primeira pessoa do singular ao se apresentarem, de diálogos diretos com o leitor e do uso de descrições, dando-lhes o tom confessional do relato de um exilado.

Como entende Vicente Llorens $^{66}$, em relação à imagem da pátria, no exílio o poeta desterrado vê com os olhos da imaginação, recordando a terra distante, formas, contornos e cores. Não só o Prado, mas também o mar, ambos citados nos poemas, podem representar essa imagem mais ampla, como a pátria inteira.

Como cada poema tem suas particularidades, consequentemente, cada cor possui suas simbologias específicas. No entanto, estas giram em torno do passado do "eu", tanto no tempo, resgatando a infância ou a fase adulta anterior ao exílio, como no espaço, evocando as pinturas do Museu do Prado, além de paisagens espanholas e mediterrâneas.

Assim, os poemas dedicados às cores, com as menções aos pintores nos quais elas predominam, propõem um roteiro de passeio pelo Museu do Prado, já anunciado no poema "1917", como uma revisita de Alberti ao Museu, somente possível através da memória.

\footnotetext{
${ }^{65}$ Segundo Zuleta, "Si consideramos la serie de poemas dedicados a los colores, encontramos también una marcada variedad de enfoques y de procedimientos. El color puede aparecer como elemento unitario, persistente a través del tiempo, en las diferentes escuelas, estilos y pintores; como elemento caracterizador de las más diversas manifestaciones de la materia; como elemento simbólico, de acuerdo con una simbología tradicional o inventada; como punto de confluencia de lo objetivo con lo subjetivo." ZULETA, Emilia de. Cinco poetas españoles: Salinas, Guillén, Lorca, Alberti, Cernuda. Madrid: Gredos, 1971, p. 360.

${ }^{66}$ LLORENS, Vicente. La imagen del la patria en el destierro [1949]. In: Estudios y ensayos sobre el exilio republicano. Sevilla: Renacimiento, 2006, p. 137-142.
} 


\section{3. Poemas sobre pintores}

Na primeira edição, de 1948, o livro A la pintura dedica poemas aos pintores Giotto, Piero della Francesca, Botticelli, Leonardo, Miguel Ángel, Rafael, Tiziano, Tintoretto, Veronés, El Bosco, Durero, Rubens, Rembrandt, Poussin, Pedro Berruguete, El Greco, Zurbarán, Velázquez, Valdés Leal, Goya, Delocroix, Cézanne, Renoir, Van Gogh, Gutiérrez Solana e Picasso.

Em 1953 o autor acrescenta novos poemas para pintores. Entretanto, como afirma Zuleta ${ }^{67}$, estes não alcançam nem a beleza formal dos anteriores, nem conseguem capturar, com tanta profundidade, a cosmovisão que origina o mundo pictórico singular de cada pintor. Em 1975, são acrescentados poemas para Miró, cuja forma tampouco apresenta a complexidade dos primeiros poemas.

O formato tríplice da obra, mesclando poemas sobre cores, pintores e instrumentos da pintura, termina em Picasso ${ }^{68}$, indicando que este pode representar para Alberti o ápice da pintura, como sugere também a dedicatória do livro. Os poemas de 1953 e 1975 são de um único tipo, pois evocam somente pintores e não possuem relação com os anteriores, sendo apenas incluídos no final do livro.

Para que conseguíssemos abarcar a diversidade e a riqueza dos poemas, selecionamos seis que homenageiam pintores importantes para a História da Pintura, concentrando-nos um pouco mais no renascimento, assim como procede Alberti na disposição de seu livro. Os selecionados são: "Giotto", "Leonardo", "El Bosco", "El Greco", "Goya" e "Picasso".

\footnotetext{
${ }^{67}$ ZULETA, Emilia de. Cinco poetas españoles: Salinas, Guillén, Lorca, Alberti, Cernuda. Madrid: Gredos, 1971, p. 365.

${ }^{68}$ Picasso foi nomeado, pelo Governo Republicano, diretor do Museu do Prado durante a Guerra Civil Espanhola (1936-1937).
} 
O poema "Giotto" ${ }^{99}$ trata do pintor e arquiteto italiano, considerado o elo entre a pintura medieval e o renascimento, pois introduziu a perspectiva e as figuras mais próximas aos seres humanos, quebrando o imobilismo e a hierarquia da pintura medieval.

O texto começa apresentando o pincel e depois traz a tela branca, o lápis, o desenho, a luz, a figura humana, as cores, o movimento e, por último, o contexto, a Idade Média: "en una edad oscura / me concediste el hábito glorioso / del hermano mayor de la Pintura" (p. 16). Assim, o poema recompõe gradualmente a imagem da pintura de Giotto.

Para explorar o estilo de Giotto, o "eu" foca-se em algumas questões-chave, como a luz e a tridimensionalidade, que reconstituem o ideal da perspectiva na pintura, uma das características principais do pintor italiano.

Outro aspecto de grande importância em sua pintura é o tema do divino, bastante destacado no início de cada estrofe, já que a palavra inicial "Laude"70 e seu complemento "Señor Dios mío" (p. 15-16) indicam louvor, contemplação e prece. Além disso, há outras palavras que reforçam esse aspecto como "tu divino rostro", “iluminado", "perenne sueño de la vida”, "solemne movimiento", "hierático mar", "ángel”, "salmo" e "hábito glorioso" (p. 15-16).

Ao mesmo tempo em que é apresentado o mundo do divino, também é introduzido o tema do humano, ressaltando a pintura, a vida e a fraternidade, como se pode comprovar no uso das expressões: "perenne sueño de la vida", "hermano pincel",

\footnotetext{
${ }^{69}$ Giotto di Bondone (1266-1337), pintor e arquiteto de estilo gótico e humanista, que utilizava a linguagem visual dos escultores para obter volume e altura realista nas figuras de suas obras.

${ }^{70}$ Canto de louvor.
} 
"hermano diseño", "hermana luz", "humana figura", "recta hermana", "hermana arquitectura", "hermano color", "fraternal violeta", "lengua pintando", "buen añil hermano", "hermano viento", "hábito glorioso del hermano mayor de la Pintura" (p. 1516).

Se os personagens pintados por Giotto são divinos, as suas aparências são humanas, características que são captadas pelo "eu", sendo transpostas para o poema:

Laude, Señor Dios mío, a la humana figura, ardiente paralela, recta hermana de la infinita hermana arquitectura. (p. 15)

Esta aproximação entre o divino e o humano nos santos que mais parecem pessoas comuns, com os dois lados complementando-se, aponta outra característica importante de Giotto: o humanismo. Assim, pode-se afirmar que, na apropriação desses elementos fundamentais de sua pintura, como a questão da luz, da perspectiva e do humanismo, o poema consegue reconstituir a imagem, o estilo e o contexto de Giotto.

O poema "Leonardo"71 homenageia o pintor detentor de diversos talentos e variadas outras habilidades como de matemático, arquiteto, engenheiro, inventor, anatomista, botânico, poeta, músico e estudioso da aviação.

Nos primeiros versos as deusas Luz, Sabedoria, Graça e Beleza preparam o nascimento de um novo deus: Leonardo da Vinci. Neste universo em perfeita harmonia

\footnotetext{
${ }^{71}$ Leonardo da Vinci (1452-1519), pintor, escultor e cientista renascentista italiano.
} 
a Luz decide ser anjo e traz o anúncio ${ }^{72}$ desse nascimento, cujo sol é simbolizado pela figura de um olho, indicando o principal eixo deste pintor, a observação científica, com a qual realizava seus estudos, inclusive pictóricos. Assim, sua pintura é definida como paixão, razão e frieza, resultante do casamento das cores com a ciência.

A partir do verso 21 o poema disseca as características do gênio. Desta forma, o pincel é comparado ao bisturi e o pintor, ao anatomista e ao cientista, fazendo o uso do microscópio, possuindo a curiosidade permanente e a habilidade de investigação incessante. Com isso, ocorre a fusão entre o pintor e o cientista da Vinci.

O "eu" evoca o pintor - "Yo lo siento llorar, enfurecido" (p. 25), relacionando-o à razão, a partir da matemática e da arquitetura, o que sugere seu estudo sobre a perspectiva, que é confirmado em seguida. Na mesma linha, são mencionados o cientista observador detalhista e a escultura — "forma" e "molde" (p. 25), que ajudam a compor a personalidade e a história de Leonardo.

Para se aproximar da complexidade multifacetada do gênio Leonardo, em seus estudos empíricos de anatomia no desvendar dos cadáveres, o poema faz uso da imagem misteriosa: "Mistério lejos del mistério" (p. 25).

O gênio também é destacado a partir do sonho de voar, chamado de sonho real, caracterizado neste poema de modo impessoal, isto é, sem o uso de primeira pessoa "Es la contemplación, es la obstinada / fijeza agotadora del detalle", "Sueño real, despierto y bien despierto, / sin tiniebla irreal que lo evapore", "Pintar el viento, reducirlo a líneas, / precisarlo en el vuelo de un segundo", "la forma, el molde, el vaciado / de su soplo visible que lo mueve", "Volar, volar, pero sabiendo el ojo / que no hay pájaro o

\footnotetext{
${ }^{72} \mathrm{O}$ que evoca um de seus quadros mais conhecidos, Anunciação (1472-1475), no qual figura um anjo realiza a enunciação à virgem, apresentando o uso inteligente da luz na composição do volume e da perspectiva.
} 
flecha que lo engañen" (p. 25), indicando o estudo do vôo dos pássaros, realizado por Leonardo. Esse modo impessoal Ihe atribui uma amplitude maior, como um sonho da humanidade, que transborda a individualidade do cientista.

Assim, o que encerra o poema é justamente "El Ojo", "el Ojo Universal” (p. 2415), que se conserva no tempo, imortal, pois, a luz, o olho e a pupila compõem o olhar, imagem constante e principal no poema, que representa a perspectiva na pintura e o lado observador do cientista Leonardo.

O poema "El Bosco" aborda o pintor e gravador holandês Hieronymus Bosch ${ }^{73}$, conhecido na Espanha como El Bosco ${ }^{74}$.

Como o pintor possuía um perfil singular em relação aos demais de sua época, de difícil classificação artística, este poema apresenta um perfil de construção um pouco distinto dos demais do livro, possuindo alto teor narrativo. A maioria de seus versos justapõe e enumera as ações, como mostra o exemplo:

\author{
Amar y danzar, \\ beber y saltar, \\ cantar y reír, \\ oler y tocar, \\ comer, fornicar, \\ dormir y dormir, \\ llorar y llorar. (p. 54)
}

\footnotetext{
${ }^{74}$ Hieronymus Bosch (1450-1516), Jeroen Van Aeken ou El Bosco, pintor holandês dos séculos XV e XVI.

${ }^{74}$ Segundo Zuleta, o poema "El Bosco" é "una perfecta adecuación del lenguaje y del ritmo al mundo extraño, fantástico y dinámico del pintor. El delirio pictórico halla sus correspondencias en el delirio verbal de las violentas secuencias de palabras, la acuñación de nuevos vocablos y la funcional organización del verso y de la estrofa, de acuerdo con el ritmo conceptual. Tal vez sea este poema la más fiel de las trasposiciones pictóricas contenidas en el libro." ZULETA, Emilia de. Cinco poetas españoles: Salinas, Guillén, Lorca, Alberti, Cernuda. Madrid: Gredos, 1971, p. 359.
} 
Com o uso desse recurso narrativo, o poema cria a visão do inferno, associado a sofrimentos sem fim: ranger de dentes, espanto, escuridão, pessoas em situações degradantes, vômito e morte, mediados pelo diabo, pois, com uma disposição visual irregular dos versos no poema, as imagens são sempre quebradas pela presença da figura demoníaca, o que Ihe dá onipresença, como um eixo no poema.

Os versos exploram o jogo de palavras para falar do diabo: "Mandroque, mandroque, / diablo palitroque", "Verijo, verijo / diablo garavijo", "Virojo, pirojo, / diablo trampantojo", "Predica, predica, / diablo pilindrica", "Guadaña, guadaña, / diablo telaraña" (p. 54-56).

Como se pode observar, o ser demoníaco é figurado sempre como astuto, mentiroso, ladino, enganador, com forma física de junções de animais, de modo que, em conjunto com sua comitiva, ele é responsável pela prática de varias violências:

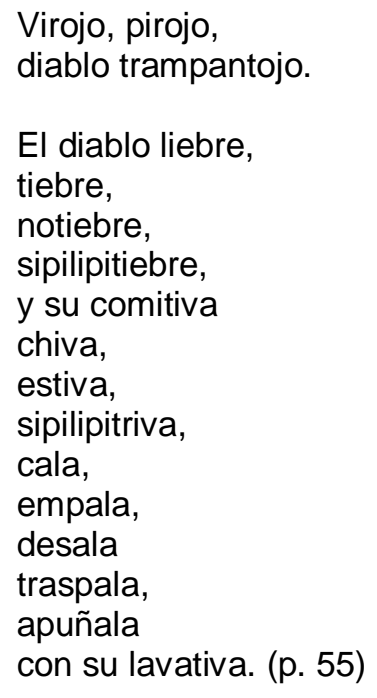


Desta forma, a linguagem utilizada para construir essa imagem do inferno é a popular, com a ajuda de onomatopéias - “Pío, pío, pío!” (p. 54), ironias, ofensas ao diabo e neologismos construídos pelas junções de animais, como no exemplo a seguir:

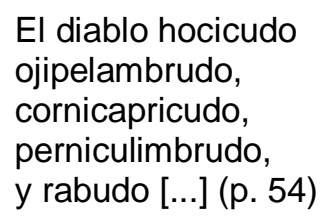

Além disso, o inferno também é composto pela luxúria, por imagens que sugerem um dos quadros mais famosos do pintor holandês, O jardim das delicias:

\author{
¡Amor hortelano, \\ desnudo, oh verano! \\ Jardín del Amor. \\ En un pie el manzano \\ y en cuatro la flor. \\ ( $Y$ sus amadores, \\ céfiros y flores \\ y aves por el ano.) (p. 55)
}

O poema que se inicia com "El diablo" (p. 54) e termina com "al infierno" (p. 56), está de ponta a ponta dominado pelo demoníaco, construindo passo a passo esse ambiente escuro, do diabo e do inferno ${ }^{75}$. O pintor só é mencionado nos versos finais, ainda que de forma indireta, com a metáfora do pincel, indicando que a sua pintura desce do céu ao inferno - "tu pincel baja al infierno" (p. 56), definindo o seu estilo de

\footnotetext{
${ }^{75}$ Segundo Gaya Nuño: “Jerónimo Bosco, ya casi español de tan escurialense y madrileño, de cuyas tablas brinca 'El diablo hocicudo, ojipelambrudo, cornicarpicudo, perniculimbrudo y rabudo', el que 'zorrea, pajarea, mosquiconejea, humea, ventea, peditrompetea por un embutido'. El Museo del Prado se llena de diablejos y de monstruecillos, El Escorial los ve volar hacia el Guadarrama. Pasan años y siglos, y los diablos parecen duendecitos, y los monstruecillos se visten de reyes [...]" GAYA NUÑO, Juan Antonio. Carta a Rafael Alberti sobre la pintura, Insula, Madrid, nº 198, p. 14, mayo de 1963.
} 
pintar, no qual o inferno adquire maior destaque do que o céu, além de constituir o clímax final.

O poema "El Greco" reporta-se ao pintor, escultor e arquiteto grego, de estilo maneirista, que desenvolveu a maior parte da sua carreira na Espanha.

$\mathrm{Na}$ busca pela origem da sua criação pictórica o poema adquire o tom interrogativo, a partir de perguntas que possuem intrinsecamente palavras reveladoras do estilo de criação de El Greco, como em “¿De dónde este volcán que arroja pliegues [...], que es capaz de hacer líquido el rayo [...] ?" (p. 82), comparando o estilo do pintor a um vulcão incandescente. Também vale ressaltar que essas perguntas não apresentam respostas no poema. No entanto, na seqüência o "eu" convida o leitor a sentir e fazer parte do mundo do pintor: "Tocad y sentiréis" (p. 83).

Para sugerir o estilo El Greco de pintar, o poema faz uso de imagens intensas como o fogo, a brasa, a lava, o vinho tinto, o redemoinho, o canhão, o enxofre, a ânsia verde, o amarelo frenesi, intercaladas com imagens sutis como o evaporado, o cego alento, a lívida turvação e o etéreo. Estas últimas caminham em direção ao universo religioso, também presente no poema, nas referências à luz, ao espírito, aos céus, às nuvens, aos anjos, à glória, ao manto, à lágrima, além do purgatório.

Note-se ainda que a imitação da estética de El Greco pode ser vista também nas descrições das imagens dos anjos e outros seres que flutuam nas obras do pintor, suspensos no ar: "los brazos os cantan, os elevan, diluyéndoos el peso" (p. 83). Tais anjos apresentam os narizes característicos e os olhos vesgos: "ángeles de narices alcuzas y ojos bizcos" (p. 82). 
Coexistem no poema os belos feios do pintor e as contradições dos quadros que juntos representam as obras de El Greco, ou seja, a convivência entre a beleza e a feiúra, o céu e o inferno: "de gloria enlodazada o infierno trasparente" e "cueva de misteriosos bellos feos, / de horribles hermosísimos" (p. 83).

No final, o poema sintetiza o estilo do pintor com a metáfora do purgatório da cor, confirmando o eterno estado de desequilíbrio entre os opostos de suas figuras:

\author{
¡Oh purgatorio del color, castigo, \\ desbocado castigo de la línea, \\ descoyuntado laberinto, etérea \\ cueva de misteriosos bellos feos, \\ de horribles hermosísimos, penando \\ sobre una eternidad siempre asombrada! (p. 83)
}

O poema "Goya" trata do pintor cujas obras abrangem uma ampla variedade de temas como paisagens, cenas mitológicas, deuses, homens, feiticeiros e figuras diabólicas.

O universo do pintor é recuperado a partir de referências diretas aos seus quadros como os toureiros Pedro Romero e Pepe-Hillo, retratados no Retrato de Pedro Romero e na série Tauromaquía; os reis de Borbón, personagens de diversos quadros como La familia de Carlos IV; o Santo Ofício, na pintura negra El santo oficio; o fuzilamento, em Los fusilamientos en la Moncloa; o cardeal, em Retrato del cardinal Luís María de Borbón y Vallabriga; a paisagem madrilena em La pradera de San Isidoro; a "maja" e os encapuzados no quadro La maja y los embozados; a procissão, na gravura Procesión de disciplinantes; a morte e o vômito, como na gravura ํo 12 da 
série Los desastres de la guerra, na qual um homem vomita sobre cadáveres e corpos mutilados, com a legenda "Para esto habéis nacido"; o disparate, como na série Los disparates e, finalmente, o enterro, no quadro El entierro de la sardina.

No poema há a ênfase em seu lado mais escuro, evocando gravuras e pinturas negras, com personagens típicos de Goya, como a velha, o demônio e outros seres deformados. Assim como nos quadros do pintor, nestes versos há a presença do irônico, do macabro e do esperpento ${ }^{76}$.

Algumas características esperpênticas presentes nestes versos assemelham-se àquelas presentes nos quadros de Goya, como a degradação dos personagens, a animalização ou fusão de formas humanas com animais, a mescla do mundo real com o pesadelo e a morte.

A imagem inicial do poema é composta por violência, estupro e sangue, com suas contraposições doçura, riso e sorriso, criando o macabro, com um diabo louco armado com faca perseguindo a luz e as trevas, o que permite apresentar também o diálogo do "eu" com este macabro:

\footnotetext{
${ }^{76}$ A teoria do esperpento é apresentada na literatura por Valle-Inclán, na obra Luces de bohemia, na qual o autor se utiliza do personagem Max Estrella, bêbado e em momentos de delírio, antes de morrer, para definir esse conceito: "El esperpentismo lo ha inventado Goya. Los héroes clásicos han ido a pasearse en el callejón del Gato [...] Los héroes clásicos reflejados en los espejos cóncavos dan el Esperpento. El sentido trágico de la vida Española sólo puede darse con una estética sistemáticamente deformada [...] España es una deformación grotesca de la civilización europea [...] Las imágenes más bellas en un espejo cóncavo son absurdas [...] La deformación deja de serlo cuando está sujeta a una matemática perfecta. Mi estética actual es transformar con matemática de espejo cóncavo las normas clásicas [...] deformemos la expresión en el mismo espejo que nos deforma las caras y toda la vida miserable de España”. VALLE-INCLÁN, Ramón María del. Luces de bohemia. Madrid: Espasa-Calpe, 1991, p. 168.

$\mathrm{O}$ esperpento em Valle-Inclán não é um barroquismo. Não se trata de algo estilizado, exagerado, usado coloquialmente ou retoricamente. O esperpentismo de Valle-Inclán passa a ser estrutura, apresentando-se como elemento-chave que propulsa esquemas de pensamento, que por sua vez se concatenam para formar uma estrutura complexa de visão de mundo. Assim, a visão do esperpento se situa como conexão entre ficção e História, como um fio condutor que nos leva a uma visão crítica do mundo, ou seja, os irrealismos do esperpento funcionam como uma representação simbólica das relações sociais para contar a História da Espanha sentida e interpretada criticamente. SANTOS, Margareth dos. Goya en negro: una visión esperpéntica. 2000. 181 f. Dissertação (Mestrado em Letras) Faculdade de Filosofia, Letras e Ciências Humanas, Universidade de São Paulo, São Paulo, 2000, p. 18-20.
} 
De ti me guardo un ojo en el incendio.

A ti te dentelleo la cabeza.

Te hago crujir los húmeros. Te sorbo

el caracol que te hurga en una oreja.

A ti te entierro solamente

en el barro las piernas.

Una pierna.

Otra pierna.

Golpea. (p.103)

Nesses versos são recriadas as imagens de Los desastres de la guerra, série de Goya que retrata a guerra pela independência da Espanha, ou seja, um olhar sobre a guerra, o enterrar de seus mortos, espécie de morte a quem vive para presenciá-la: “¡Huir! / Pero quedarse para ver, / para morirse sin morir” (p. 103). É a agonia de ver a Espanha morrendo: "Aspavientos de la agonía. / Cuando todo se cae / y en adefesio España se desvae [...]" (p. 103).

Tal mergulho em Goya atinge o nível das inversões e dos paradoxos do universo do pintor, como em "Y la gracia de la desgracia. / Y la desgracia de la gracia" (p. 104) ou em:

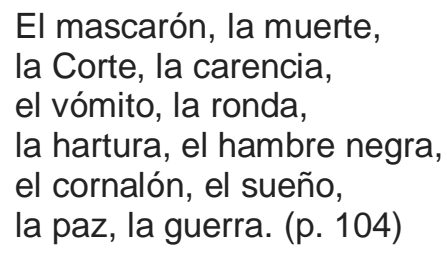

Com o andamento do poema, o "eu" vai se questionando sobre as origens da inspiração ou criação pictórica nas obras de Goya, o que se dá através da repetição da pergunta “¿De dónde vienes [...]?” (p. 104-105). 
Ao avançar na representação da realidade da época do pintor, o poema aproxima-se de seu mundo pictórico, associado também aos esboços, à série Los disparates, aos animais de chifre e à morte.

Assim, o poema caminha para o fim das ilusões, como se pode observar nos versos próximos ao final, nos quais é apresentado o Gaudeamus ${ }^{77}$, seguido pela realidade —-"sueño de la mentira. / Y un entierro / que verdaderamente amedrenta al paisaje" (p. 105), uma denúncia dos horrores da humanidade que Goya exercita bastante nos anos finais de sua vida.

O poema "Goya" é uma evocação do mundo do pintor, de suas obras e dos personagens que habitam esse complexo universo - de graça e horror, repleto de contraposições, cujo centro e ápice encontram-se no próprio pintor, que só é mencionado diretamente nos três últimos versos do poema, com destaque para o paradoxo: "Pintor. / En tu inmortalidad llore la Gracia / y sonría el Horror" (p. 105).

O poema "Picasso" reporta-se ao pintor, escultor e desenhista espanhol do século XX.

A imagem inicial é de um paraíso perdido, a partir das cores da paisagem mediterrânea evocadas pelo "eu", ou seja, um paralelo entre Cadiz, cidade natal de Alberti, e Málaga, cidade onde Picasso nasceu, pois as palavras e as cores que os primeiros versos apresentam fazem referências ao livro de poemas Marinero en tierra, do próprio Alberti:

Málaga.

Azul, blanco y añil

postal y marinero. (p. 131)

${ }^{77}$ Na tradição do carpe diem, "Gaudeamus" significa "alegremo-nos", indicando as comemorações ou festas estudantis. 
O "eu" evoca sua terra natal a partir de suas lembranças, de onde acessa o touro na fase azul de Picasso: "De azul se arrancó el toro / ¡Oh guitarra de oro, / oh toro por el mar, toro y torero!" (p. 131). A Espanha é definida com as imagens de teia de aranha, foice, sufoco, entranhas e pau de sebo:

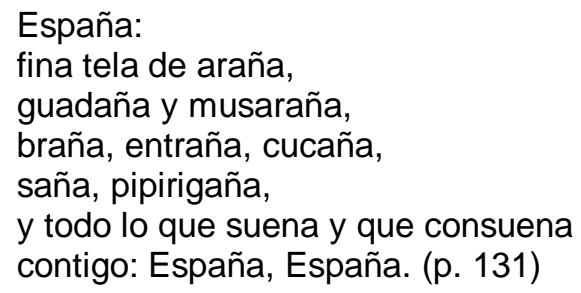

Desde a infância, Picasso possuía uma paixão pelos touros, símbolos do país, o que se refletiu mais tarde em suas pinturas de temas taurinos como na releitura da série Tauromaquía, de Goya, reinterpretada por Picasso em Tauromaquía de Pepe Hillo, o que Ihe rendeu na França o apelido de "le petit Goya". Sendo assim, a imagem do "toro azul" neste poema é a metáfora do próprio pintor Pablo Picasso em sua taurina fase azul:

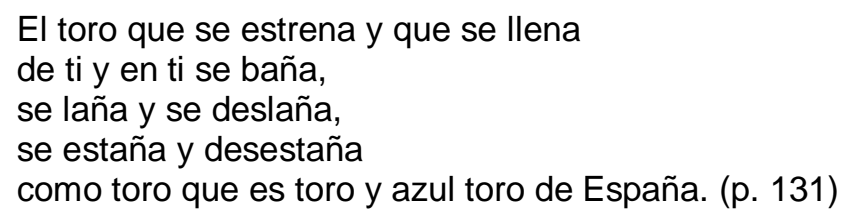

Neste poema, o universo de Picasso é recriado com referências a suas fases azul e rosa, aos seus quadros, como em Mulher passando ferro, e também a sua 
biografia, como nas lembranças dos estudos dos grandes pintores --"suerte de la línea, I de la aventura del color" (p. 132), pois o Museu do Prado é evocado no exercício matutino de copiar os grandes mestres da pintura a partir de seus quadros, assim como Alberti $^{78}$.

Em seguida, o poema move-se do Prado à França, com a distância da Espanha descrita pela separação, com a imagem do cataclismo, da rigidez da mortalha e do abismo. Tal fase associa-se à natureza morta de Picasso, pintada na França, e às referências à obra $A$ garrafa de Vieux Marc, onde há uma mesinha sobre a qual são colocados uma taça, uma garrafa de Vieux Marc e um jornal com o título de "Le journal".

$\mathrm{Na}$ seqüência, no cubismo, o "eu" se pergunta qual a atitude do touro encurralado perante uma viela aparentemente sem saída. A primeira resposta é "miedo", que é sugerido na imagem do touro nas corridas em ruas estreitas. No entanto, a saída não é a morte e sim a vida: "vida, vida, vida" (p. 133).

Ao invés de o toureiro sentir medo, quem o sente é o touro, ou seja, os papéis estão invertidos, o que reforça a associação entre Picasso e o touro, como seres encurralados: "Aquí el toro torea a veces al torero. / Es el toro quien tema la cogida. / Con las astas dibuja" (p. 133).

Os horrores se tornam a razão e o sonho da poesia: "Canta el color con otra ortografia / y la mano dispara una nueva escritura" (p. 133). Então o "eu" se pergunta na Guerra Civil Espanhola qual será a atitude do touro perante a estocada. Como pintor, sua resposta à guerra é o quadro Guernica (1937).

\footnotetext{
${ }^{78}$ Picasso fez várias releituras de quadros famosos como Las meninas, de Velázquez, Mujeres de Argel, de Delacroix e $O$ café da manhã campestre, de Manet, entre outros.
} 
Esta é a obra que mantém ativa a memória dos espanhóis sobre os horrores da guerra e a resposta da arte à violência da Guerra Civil Espanhola, já que a arte é a arma de Picasso, com a qual expressa o seu compromisso político, que o leva a ingressar no partido comunista e apoiar diretamente o governo republicano. Assim, o poema "Picasso" não é somente uma homenagem ao pintor e sua pintura, mas também um reconhecimento de seu comprometimento político, contra a guerra e a morte, com o qual se identifica Alberti.

Guernica corresponde à metáfora da arrancada do touro, de não sucumbir à guerra, e sim de produzir uma nova realidade. Desta forma termina o poema: com o combate à guerra:

Guernica.

Dolor al rojo vivo.

...Y aquí el juego del arte comienza a ser un juego explosivo. (p. 134)

Embora os poemas sobre pintores se diferenciem tanto na forma como na temática, possuem alguns aspectos em comum, como o uso da terceira pessoa para dar voz a alguém ou falar de sua pintura, tendência na maioria dos versos. Na maior parte dos versos a forma de expressão procura a naturalidade da prosa, com o uso de enjambement. A exceção ocorre, por exemplo, na composição do inferno em "El Bosco", pois neste caso o poema faz uso de palavras lançadas uma atrás da outra, criando a fluência do jogo para aludir ao demoníaco.

No entanto, varia o modo de mencionar o pintor: no final do poema, como no caso de "El Bosco" - "Pintor en desvelo: / tu paleta vuela al cielo [...] tu pincel baja al 
infierno" (p. 56) e "Goya" - "Pintor. / En tu inmortalidad Ilore la Gracia / y sonría el Horror" (p. 105). Já em "Leonardo", é citado já no início, —“Y al cabo la Belleza total, sola: / —Sueño —ofreció—que me llaméis Leonardo" (p. 24), assim como em "Picasso" — "como toro que es toro y azul toro de España. / P i c a s s o : / maternidad azul, arlequín rosa"(p. 131). Em outros, como em "Giotto" e "El Greco" o pintor não é mencionado diretamente.

Em relação à temática ${ }^{79}$, a variedade se explica devido à busca da aproximação com o universo de cada artista. A presença do demoníaco, por exemplo, está em pintores que utilizaram essa temática em seus quadros, como em "Goya" e no pintor flamengo "El Bosco", em maior grau.

Além disso, ao evocar os pintores do Prado ${ }^{80}$, o "eu" refere-se diretamente a suas obras ou a personagens de seus quadros. Porém, não se prende evocar apenas as pinturas que pertencem ao acervo do Museu, já que utiliza as obras mais significativas e necessárias para poder reconstituir o universo de cada pintor.

Sendo assim, comprova-se que os poemas sobre pintores exploram cada pintor a partir da biografia, do contexto e das pinturas, de acordo com suas particularidades, recriando o mundo de cada um deles. Entretanto, não seguem uma mesma forma, posto que os pintores possuem estilos e históricos bem variados, o que se reflete nesses versos, que se adaptam ao universo pictórico de cada artista.

\footnotetext{
${ }^{79}$ Nos poemas sobre pintores, segundo Zuleta, "a través de lo meramente descriptivo el poeta evoca un mundo pictórico, un clima y un momento determinado [...] Otros poemas se preocupan más por definir el modo de captación de la realidad propio del pintor abordado." ZULETA, Emilia de. Cinco poetas españoles: Salinas, Guillén, Lorca, Alberti, Cernuda. Madrid: Gredos, 1971, p. 357-358.

${ }^{80}$ No caso de Picasso, embora suas obras não estejam no Museu do Prado, já que este só abriga obras produzidas até o século XIX, o pintor possui grande ligação ao Museu, tendo inclusive sido eleito diretor deste durante a Guerra Civil.
} 


\section{4. Poemas sobre elementos da pintura}

O livro A la pintura dedica diversos poemas a elementos do universo pictórico: "A la pintura", "A la retina", "A la mano", "A la paleta”, "A la pintura mural”, "Al lienzo", "Al pincel”, "A la línea", "A la perspectiva”, "Al claroscuro", “A la composición”, “Al color", "Al ropaje", "A la luz", "A la sombra", "Al movimiento", "Al desnudo", "A la gracia", "A la acuarela", "A la divina proporción".

Para aproximarmo-nos dessa diversidade, foram selecionados poemas que abrangessem as três subclasses de elementos aos quais se dedica o poeta: objetos concretos como a retina e a paleta, abstratos como a perspectiva, o claro-escuro e a graça, e materiais ou técnicas de pintura como no caso da aquarela. Assim, foram escolhidos os seguintes poemas: "A la retina", "A la paleta", "A la perspectiva", "Al claroscuro", "A la gracia" e "A la acuarela".

O poema "A la retina" homenageia a parte do olho responsável por captar e traduzir as imagens da visão para o cérebro, elemento fundamental também para o pintor.

A visão constitui o tema central do poema, primeiramente destacando a sua função fotográfica, já que o olhar possui a capacidade de captar as tantas imagens que o mundo oferece para o cérebro poder "atesorar", ou melhor, reuni-las e guardá-las na memória.

A forma física da retina, redonda, é explorada, como uma tela refletora no fundo dos olhos - "profundo espejo que atesora" (p. 17) e, por extensão, na companhia da menina dos olhos — “niña de luz" (p. 17), do formato redondo do olho —-jardín redondo" 
e "flor circular" (p. 17) ou dos elementos circulares: "sol cerrado" e "abierta luna", "hora de sol sin hora" (p. 17).

Essa imagem expande-se, possibilitando o sentido de janela aberta para o mundo — "donde mora / de par en par pintada la belleza", "ajimez a la mar de la ventura" (p. 17), completada pela amplitude —-el sinfín de la naturaleza", "noche de grandeza", "hora de sol sin hora", 'torre del homenaje de la vida", "pintor de los pintores", "fuente inmortal de la pintura" (p. 17) - e pela onipresença, através dos paradoxos: "siempre vivaz, aunque dormida", "si sol cerrado, noche de grandeza, / si abierta luna; hora de sol sin hora" (p. 17).

Além disso, com a metáfora da retina-pintora, alusão à criação da visão no cérebro, o poema também focaliza a beleza das cores - "donde mora / de par en par la belleza", "flor circular que irisa en su cabeza / del rayo negro al rubio de la aurora", “¿qué sería sin ti de los colores, / niña de luz, pintor de los pintores?” (p. 17), ressaltando a importância da retina no reconhecimento destas cores no mundo, pois é preciso conhecê-las para poder imitá-las ou recriá-las na pintura.

Para reconstituir a retina, o poema trabalha tanto a forma física, através de termos relativos ao redondo, evocando a imagem do olho, como também sua função fotográfica para a pintura, ou seja, de caixa observadora do mundo, que permite ao pintor exercer a sua profissão com beleza, detalhes e perfeição.

O poema "A la paleta" trata do elemento que serve como plataforma para o pintor ordenar as diferentes cores e realizar a pintura. Destacam-se a sua matéria, composta de madeira, e seu formato físico, plano — “infinita haz", "abanico, ala redonda, escudo, / espejo", "superficie pura" (p. 23), apontando também os espaços onde são depositadas 
as tintas coloridas como "Pozo y brocal" (p. 23), pois a pintura é resultado de como são misturadas e utilizadas essas cores: "color, luces y sombras", "arcoíris" (p. 23).

Além disso, é explicitada a sua função para a pintura, através do processo de trabalho com essas tintas - "donde siega el pincel, gavilla, amasa / y entre color, luces y sombras, pasa / de mar radiante a tiempo anubarrado", "medita, viene y va, mide, acompasa", "traspasa" (p. 23)— que, com a ajuda do paradoxo —-"espejo que al vestir queda desnudo" (p. 23), compõe a imagem da transposição dessas cores da paleta para a pintura, além recorrer ao mito grego de Polifemo: "frente asida a la mano que traspasa / tu ojo de Polifemo enamorado" (p. 23).

É ressaltada tanto a característica de origem, como também de base e plataforma para a preparação da pintura ou como espectro de múltiplas possibilidades - "A ti, lecho y crisol de la Pintura", "entre color, luces y sombras, pasa / de la mar radiante a tiempo anubarrado" (p. 23), o que é reforçado nos três últimos versos do poema ao concentrar várias definições do objeto homenageado: "En ti se cuece la visión que nace. / Tu firmamento el arco-íris pace. / A ti, lecho y crisol de la Pintura" (p. 23).

No poema, portanto, a paleta é representada, tanto na forma física, de tábua plana para o depósito das tintas, como nas funções de base, origem ou acervo de possibilidades para a pintura, o que permite ao artista poder realizar o seu trabalho com as cores.

O poema "A la perspectiva" presta homenagem ao conceito renascentista que integrava os conhecimentos matemáticos de óptica e fisiologia da visão para a composição da profundidade na pintura a partir da representação de planos. 
Para apresentar a perspectiva, o poema compõe a imagem da ilusão de óptica — "engaño ideal, por quien la vista / anhela hundirse", "conquista / de la espaciada atmósfera en lo plano" (p. 57), com a tese de que a vista almeja ser enganada por tal ilusão, criando uma espécie de simbiose entre a visão e a perspectiva na pintura.

Vale ressaltar que essa ilusão visual é causada pela distância entre os planos da pintura, ou seja, pelo efeito de profundidade, que é explorado no poema: "prolongada en mano, / yendo de lo cercano a lo lejano", "sinfín, profundidad", "al fondo del balcón cercano / decides que la mar lejana exista" (p. 57).

Entretanto, para que o efeito em questão seja construído, são necessários estudos matemáticos, representados nos versos a partir do uso de contrários "aumento, valor de los valores, / vaga disminución de los colores" (p. 57) - e de expressões que indicam a ordenação e a perfeição: "música celestial, arquitectura" (p. $57)$.

Tais procedimentos são especificados no uso da perspectiva através dos contornos e da linha como base para constituir a pintura: "Los ámbitos en ti fundan su planta. / La línea con el número te encanta" (p. 57).

Ao final, o poema traz a definição da importância da perspectiva para a pintura. Nesta exaltação é utilizado um aforismo de Leonardo da Vinci, mestre italiano para definir a perspectiva como dirigente da pintura — "brida y timón de la Pintura" (p. 57), aludindo ao contexto em que esse recurso foi desenvolvido e plenamente utilizado: a época do Renascimento. 
O poema "Al claroscuro" trata de a uma das estratégias inovadoras renascentistas, constituída pelo contraste entre a luz e a sombra, que cria o efeito do volume em um objeto, sem utilizar linhas de contorno.

O volume é marcado no poema a partir da justaposição entre luz e sombra, pois para serem destacados o brilho e a luz, é preciso utilizar a sombra como fundo, o que está apresentado em "nocturno, por la luz herido, / luz por la sombra de repente" e "claro en la noche y por el día oscuro" (p. 67).

Para marcar o uso do claro-escuro, o poema recorre aos contrários e paradoxos: "claro ofensor de súbito ofendido", "Si el día tiembla, tú, noche valiente; / si la noche, tú, día enardecido", "A ti, contrario en busca de un contrario", "adverso que al morder a su adversario / clava la sombra en una luz segura" (p. 67).

Este contraste intensifica-se tanto que adquire o status de batalha, luta entre a luz e a sombra, o que Ihe dá maior dramaticidade —-"arrebatado, oscuro combatiente", "A ti, acosado, envuelto, interrumpido, / pero de pie, desesperadamente", "Tu duro batallar es el más duro" (p. 67) e gera violência: "herido", "herida" e "clava" (p. 67).

Ocorre neste poema uma identificação entre o claro-escuro e o pintor Rembrandt, o que é indicado por palavras que sugerem o perfil desse artista de capacidade especial para expressar emoções, como se pode notar nas formas "arrebatado", "envuelto", "desesperadamente", "enardecido" ou no adjetivo "febril" (p. 67). Como o pintor holandês foi um grande mestre no uso do contraste e do claroescuro em todas as fases de sua pintura, o poema identifica esse recurso ao pintor: "Rembrandt febril de la Pintura" (p. 67). 
Portanto, para criar esse objeto abstrato, o poema "Al claroscuro" recorre aos seus elementos constituintes, como a luz e a sombra, os contrários e os contrastes, além da evocação de Rembrandt, um mestre do claro-escuro.

O poema "A la gracia" presta homenagem à qualidade que a pintura possui de se tornar atrativa perante os olhos de seus observadores.

No decorrer dos versos o "eu" brinca com os vários possíveis sentidos da palavra "gracia", como o engraçado — "burladora, inefable travesura", "la agracia de tu gracia", o inocente, o agradável ou o atrativo-"caricia virginal", "la agracia de tu gracia es resistirte, / correr, volar, asirte, desasirte" (p. 113) — evocando a sensualidade do mito das Cárites $^{81}$, divindades gregas da Beleza.

Tais entidades são as responsáveis por espalhar a alegria na natureza e no coração dos homens: "divina, corporal, preciosa", "aura", "suspendido seno que recrea / la perfección tranquila de la rosa", "sal que aletea" e "diosa" (p. 113).

Como essas divindades foram representadas por muitos quadros e esculturas de diversos artistas de variadas épocas com o nome de "As três graças", evocam as aulas de desenho e pintura do jovem artista Rafael Alberti, copiando Las tres gracias: "y ante la mano en vuelo delinea / tu fugitiva, rubia espalda, diosa" (p. 113).

Por outro lado, estas aulas de copiar as deusas são também associadas pelo "eu" ao elemento fugaz, ou seja, ao inapreensível — "el aura imperceptible", "huidiza, resbala, airosa", "fugitiva", "fino relámpago, destello", "inefable” (p. 113), com o final do poema encaminhando para o universo do indizível: "A ti, yo no sé qué de la Pintura" ( $p$. 113).

${ }^{81}$ Gratiae em latim e Gracias em espanhol. 
Assim, para representar esse conceito abstrato, o poema explora os vários possíveis significados do universo do elemento homenageado, no entanto, sem conseguir precisar sua função na pintura. Paradoxalmente, quanto mais ele insinua a dificuldade de compreender a "gracia", mais se aproxima de sua definição, como algo intangível.

O poema "A la acuarela" presta homenagem à técnica de pintura que utiliza tintas diluídas em água, técnica adequada para criar imagens de transparência e luminosidade.

Sua imagem principal, a água, atravessa o poema todo, de modo a exaltar seu aspecto líquido —-mojada", "abrevadora frente", "agua primaveral", "lluvia florida", "sumergida", "líquido", "fresca", "bebida", "alivio de la sed", "llorada", "te agotas", "río" e "mar" (p. 123) - evocando a mitologia na imagem da ninfa das águas: "ninfa de acequias atanores" (p. 123).

Associa-se à ninfa outra propriedade da água, a capacidade de deslocamento do líquido — "expandida", "corriente", "corres", "creces” e "río hacia el mar" (p. 123), de modo a dar ênfase à rapidez, necessária no uso da aquarela, pois se não houver rapidez, a água evapora-se e a tinta pintada seca antes que o trabalho esteja terminado: "alma ligera", "cuerpo de premura", "corres", "creces" e "amaneces" (p. 123).

Além disso, a propriedade de ser límpida, atribuída à aquarela, retoma a imagem da água, além de aludir às características de iluminação e de transparência dessa técnica de pintura: "límpida", "inmácula”, "trasparente", "espejo" e "luz" (p. 123).

De um lado, estão presentes os pigmentos das cores — "rosa", que são diluídos na água, gerando imagens de conforto e de felicidade, compondo a técnica da 
aquarela: "jubilosa", "alivio", "feliz", "primaveral" e "florida" (p. 123). De outro lado, o pincel, com sua secura e suas cerdas, contrapõe-se à água e seu universo de beleza e conforto: "su cabellera ardiente", "fresca y mitigadora luz bebida", "alivio de la sed de los colores" (p. 123).

O pincel é visto como elemento capaz de transferir a pintura ao papel, ou seja, de pintar: "Llorada de tus ojos, corres, creces, / feliz te agotas, cantas, amaneces" (p. 123). No entanto, nesta imagem, ao mesmo tempo em que se mostra a tristeza na imagem do pincel chorar a tinta, também é apresentada a felicidade do mesmo em se esgotar.

Desta forma, compõe-se a imagem do esgotamento, esvaziamento e, ao mesmo tempo, a da abundância de água e cores, correndo com a pintura como um rio em direção ao mar, oposição que retrata a transferência do pigmento da paleta, via pincel, para o quadro. Os versos apresentam imagens que buscam construir essa forma de pintar, como o líquido que o atravessa, desaguando no verso final: "río hacia el mar de la Pintura" (p. 123).

Assim, o poema cria a imagem central do encontro do pó colorido com a água, saciando a sede do pincel seco, que se desloca feliz em direção à pintura, como um rio para o mar, o que compõe a técnica da aquarela.

Todos esses poemas dedicados aos instrumentos ou elementos da pintura apresentam os títulos em caráter de homenagem, já que os mesmos começam sempre com "A la" ou "Al", como uma forma de dedicatória, por exemplo: "Al pincel”, "A la retina" ou "A la pintura". 
Quando o objeto é concreto, o poema volta-se para o aspecto físico do instrumento homenageado, quando é abstrato, busca outra forma de aproximação, recorrendo a elementos afins de seu contexto e, quando se trata de um tipo de pintura, procura descrever sua técnica. Para tanto, recorre à forma clássica do soneto para tratar desses elementos, elevando sua importância, já que esses simples elementos usados para pintar não costumam estar relacionados a formas nobres.

Quanto à distribuição dos versos, os poemas são muito parecidos, com o início das três primeiras estrofes com o uso de versos que descrevem e qualificam o objeto homenageado. No verso final, ao concluir a definição do elemento homenageado no poema, há a exaltação da importância que ele possui, pois, alude a sua função na atividade da pintura, terminando todos os sonetos com a expressão "de la Pintura", com esta última palavra escrita em letra inicial maiúscula, o que eleva mais ainda a posição dessa arte.

\subsection{Considerações sobre A la pintura}

A observação dos poemas selecionados demonstra como o livro $A$ la pintura recria o Prado, evocando os pintores, os quadros e as cores das obras de seu acervo, constitutivas da vivência de Alberti. As imagens evocam a adolescência do autor e seus primeiros contatos com as obras do Museu ${ }^{82}$.

\footnotetext{
${ }^{82}$ Segundo Henares, o "Museo en adelante va a ser símbolo de muchas realidades importantes, la juventud, un modelo de cultura civil bárbaramente abolido, el matrimonio del pueblo en peligro, y con esta importancia emerge y domina la gran elegía que es el poema A la pintura, a la vez que un esperanzado inicio del retorno." HENARES, Ignacio. La pintura y la estética en Alberti. Cuadernos Hispanoamericanos, Madrid, nº 485-486, p. 198, nov./dic. de 1990.
} 
O "eu" busca o passado saudoso e a terra distante, ou seja, o paraíso perdido a partir de uma distância dupla, tanto temporal como espacial, desde a maturidade vital e poética, o que pode ser exemplificado com o poema "1917", na relação entre pintura e poesia, uma manifestação da visão integradora das artes, que caracteriza a obra de Alberti.

De acordo com García Montero ${ }^{83}$, $A$ la pintura estava em fase de produção, em 1945, quando chegou a noticia do final da Segunda Guerra Mundial. Então Alberti fez uma declaração de que dedicava este livro à paz e ao triunfo da inteligência e da justiça contra a barbárie, desejando que triunfasse de novo a poesia, a linha, a cor e que o sangue derramado não tivesse sido em vão. Este é um livro de celebração, um canto consolador. Para tanto, utiliza a exaltação da natureza e da beleza estética humana ao descrever o paraíso da pintura, as recordações do Museu do Prado e o estilo de cada um dos pintores.

Segundo Crispin ${ }^{84}$, em $A$ la pintura, o conceito de arte presente é o burguês, de arte pura, contemplativa. Sendo assim, o Museu do Prado nesses poemas representa o paraíso perdido da arte, já que, com a guerra e os bombardeios, esse paraíso está ameaçado, transformando-se em um verdadeiro inferno. A visão realista e negativa do Museu só aparece na terceira parte do poema "1917", pois, no restante do livro impera a contemplação.

Os poemas dedicados aos pintores são os mais diversificados em relação à forma. Cada um aproxima-se do estilo de cada pintor homenageado a partir da visão de

\footnotetext{
${ }^{83}$ GARCIA MONTERO, Luis. Alberti, poeta del exilio. Cuadernos Hispanoamericanos, Madrid, ${ }^{\circ}$ 485-486, p.186, nov./dic. de 1990.

${ }^{84}$ CRISPIN, John. Los tres paraísos: religioso, estético y marxista en Noche de guerra en el Museo del Prado. Insula, Madrid, no 40 (467), p. 3, oct. de 1985.
} 
Alberti, tentando recriar suas cosmovisões singulares. Em seu mundo poético, os quadros dos pintores constroem uma predominância de cores em cada período artístico, uma tendência cromática predominante em cada época, indo da Idade Média ao Impressionismo.

A sequência das cores no livro —azul, vermelha, amarela, verde, negra e branca - devem-se ao agrupamento de quadros na predominância de uma cor em determinada época: os pintores renascentistas estão próximos do poema "Azul", Goya está próximo ao "Negro", e os impressionistas estão ao lado do "Branco",55.

Em $A$ la pintura, os quadros estão separados por escolas artísticas, ordem que tal vez seja uma tentativa de recriação espacial do Museu: os poemas apresentam um roteiro de um passeio pelo Prado, já delineado desde o primeiro texto, o "1917". E os elementos da pintura elevam a importância desta arte como homenageada, mostrando as técnicas utilizadas pelos grandes pintores, presentes no Prado.

A la pintura recria o espaço a partir da evocação de vivencias do passado. Portanto, cores, pintores e quadros configuram o paraíso perdido de Alberti, destruído com a Guerra Civil e o exílio. Nessa medida, a obra apresenta a beleza e a arte como respostas à violência, à morte e aos horrores da guerra.

\footnotetext{
${ }^{85}$ Esse Museu é a referencia da Historia da pintura para o autor. Desta forma, o livro extrapola a abrangência do real acervo do Prado, já que suas coleções não incluem obras impressionistas e modernas.
} 


\section{NOCHE DE GUERRA EN EL MUSEO DEL PRADO}

A finales de 1932 me encontraba en Berlín con María Teresa, pensionado por la Junta de Ampliación de Estudios para estudiar los movimientos teatrales europeos. Allí conocí a Erwin Piscator, gran director de escena, a Bertolt Brecht, ambos muy jóvenes aún, a Ernest Toller, dramaturgo, que se suicidó más tarde en Nueva York, y a muchos más artistas, escritores e intelectuales que el nazismo arrojó de Alemania, en donde ya, en aquel final de 1932 no se podía vivir. Un tremendo clima de violencia la sacudía en todas direcciones. El hambre y la desocupación andaban por las calles, cruzadas de escuadras nazis, que pateaban las aceras, salpicando de agua de los charcos a los aterrados transeúntes. Hitler se disponía ya, como en un gran guiñol, a instalar sus absurdos bigotes y brazos gesticulares tras el humo y las llamas del incendio del Reichstag. En ese momento se me ocurrió viajar, por primera vez, a la Unión Soviética, que fue para mí entonces como realizar un viaje del fondo de la noche al centro de la luz.

Rafael Alberti 
A peça Noche de guerra en el Museo del Prado foi publicada em 1956, 20 anos após o início da Guerra Civil e o salvamento dos quadros do Museu do Prado, em novembro de 1936, ação da qual participou Alberti. O livro é composto de apenas um prólogo e um ato, que apresenta personagens saindo dos quadros para discutir a Espanha, a guerra e a preservação do patrimônio do Museu do Prado.

Esta obra possui características que a aproximam da concepção de teatro épico $^{86}$, desenvolvida por Bertolt Brecht, autor e diretor teatral com o qual Alberti mantinha contato desde 1932, quem leu e opinou sobre a primeira versão da obra:

El mismo Bertold Brecht pretendía montarla en su Berliner Ensemble para conmemorar el vigésimo aniversario del sitio de Madrid durante la guerra civil española. Alberti viajó a Berlín para discutir con el director detalles de la planeada producción, pero la muerte de Brecht impidió la realización de este proyecto. Brecha fue quien aconsejó a Alberti la redacción de un prólogo que proveyera el marco externo de la obra $[\ldots]^{87}$

\footnotetext{
${ }^{86}$ Segundo Rosenfeld, o teatro épico para Brecht diz respeito a um teatro que se opõe ao teatro clássico tradicional - teatro aristotélico, linear, com unidades de tempo, espaço e ação- com o desejo de não apresentar apenas as relações inter-humanas individuais, mas também as determinantes sociais dessas relações. Na concepção marxista o ser humano deve ser concebido como o conjunto de todas as relações sociais. Diante disso, a forma épica é, de acordo com Brecht, a única capaz de apreender aqueles processos que constituem para o dramaturgo a matéria para uma ampla concepção do mundo. O intuito didático do teatro brechtiano é apresentar um palco cientifico capaz de esclarecer o público sobre a sociedade e a necessidade de transformá-la. Se no teatro aristotélico a ilusão e a catarse geram a passividade no público, no teatro épico o distanciamento e a não-identificação entre os personagens e os espectadores proporcionam o raciocínio e a ação transformadora na plateia. Nesta forma épica de teatro, a atuação é substituída pela narração, possibilitando a crítica da sociedade, levando o espectador a reagir criticamente, ou seja, despertando-o como um ser social. ROSENFELD, Anatol. O teatro épico. 4a ${ }^{a}$ ed. São Paulo: Perspectiva, 2006. (Série debates), p. 145-152.

${ }^{87}$ CRISPIN, John. Los tres paraísos: religioso, estético y marxista en Noche de guerra en el Museo del Prado. Insula, Madrid, no 40 (467), p. 3, oct. de 1985.
} 
Todos os trechos de Noche de guerra en el Museo del Prado citados neste capítulo são baseados na edição de $1956^{88}$. Vejamos a seguir a estrutura da peça, começando pelo estudo do prólogo.

\subsection{O prólogo}

O prólogo apresenta as características principais de Noche de guerra en el Museo del Prado, como o cenário, o tempo, a atuação dos personagens e as imagens pictóricas. O cenário da peça é uma reconstituição do salão central do Museu do Prado, ambiente no qual se instala um grande telão branco cinematográfico, usado no prólogo para a projeção dos quadros que descem ao subsolo do prédio ${ }^{89}$.

O tempo, revelado pelo narrador-autor no início, é uma noite de novembro de 1936, na qual se dá o episódio do salvamento dos quadros do Museu do Prado. Além deste, que se trata do tempo principal, durante a peça os personagens também se referem a datas mais remotas da História da Espanha.

Para completar o tempo, os personagens, já apresentados na anotação cênica anterior ao prólogo, em sua maioria, são os retratados por quadros e gravuras de Goya, como no início do século XIX, vestidos com trajes da época da Guerra da Independência (1808), além de outros, advindos de quadros do passado, e de uma mesa do século XVI no palco. Desta forma, as presenças de personagens do passado

\footnotetext{
${ }^{88}$ ALBERTI, Rafael. Noche de guerra en el Museo del Prado. (Aguafuerte, en un Prólogo y un Acto). Buenos Aires: Losange, 1956.

${ }^{89}$ Segundo Crispin "[...] en este prólogo, según los cuadros, desfilan ante los ojos de Alberti camino de los sótanos del museo, y se proyectan como diapositivas en el telón de fondo para el público, la visión del autor se desdobla entre presentes y pasado. Así, los cuadros dejan de existir como tales imágenes, pero adquieren valor en función de un contenido político-social cuando sus personajes vuelven al escenario y cobran vida como combatientes para alentar al público a la revolución." CRISPIN, John. Los tres paraísos: religioso, estético y marxista en Noche de guerra en el Museo del Prado. Insula, Madrid, nº 40 (467), p. 3, oct. de 1985.
} 
e do narrador-autor cumprem a função épica de distanciamento entre a peça e o leitor/espectador, estimulando a reflexão do público.

A peça inicia-se a partir da evocação no texto e da projeção no telão dos eventos recordados pelo autor ${ }^{90}$ no prólogo. No entanto, pouco a pouco, o individuo vai desaparecendo e o enredo vai se convertendo na história coletiva de um povo, da pintura, dos quadros e pintores que encenam o Museu e resgatam a História da Espanha.

Nesta parte da peça, a pintura é evocada através da citação de trecho do poema "1917" de A la pintura para descrever a relação do narrador com o quadro Las tres gracias, ao mesmo tempo em que essa obra é projetada na tela:

Autor [...] (Al retirarse el rayo de luz que ilumina el rostro del Autor, aparecen en la pantalla "Las Tres Gracias", de Rubens.)

Yo no sabía entonces que la vida tuviera Tintoretto - verano-, Veronés - primavera-. $\mathrm{Ni}$ que las rubias Gracias de pecho enamorado corrieran por las salas del Museo del Prado.

(Pausa ligera.) Así eran las tres claras deidades... (p. 10)

${ }^{90} \mathrm{O}$ fato do narrador só aparecer no prólogo e sair de cena no ato único é explicado por CRISPIN: "El autorprotagonista experimenta también, en una especie de pesadilla, un descenso de los infiernos. Como prototipo del mundo burgués, ha pasado simbólicamente por dos fases purgativas: la pérdida del paraíso de la inocencia infantil y de la fe religiosa (crisis que Alberti ya había expresado en Sobre los Ángeles), y ahora, la pérdida de un segundo paraíso terrenal creado por la cultura y el arte. Como tal personaje burgués, el autor-personaje no volverá a aparecer en la obra. La salvación en un tercer paraíso prometido sólo será posible para el pueblo: los personajes populares de los cuadros de Goya, los milicianos del "36" y del público politizado que no sólo contemplará la acción sino que participará en ella e, inspirado por el arte en su función social, continuará la tarea irreversible de la revolución proletaria." Segundo Crispin, nesta obra, o dramaturgo se comunica com o seu público mediante uma estrutura simbólica, combinando a técnica de distanciamento — de acordo com a fórmula do teatro épico de Brecht —com uma dimensão mítica, a qual se baseia na evocação do paraíso perdido, recorrente na obra de Alberti. CRISPIN, John. Los tres paraísos: religioso, estético y marxista en Noche de guerra en el Museo del Prado. Insula, Madrid, $\mathrm{n}^{\circ}$ 40 (467), p. 3, oct. de 1985. 
Em uma narração concisa, com a ajuda do narrador-autor e de personagens que saem dos quadros do passado, o prólogo cumpre a função didática de apresentar o Museu a quem não o conhece. Trata-se de um catálogo do que vem a seguir, juntando signos pictóricos com signos verbais, para retratar o clima de tensão da violência da guerra que afeta o povo e ameaça o seu valioso patrimônio artístico, presente no Prado, o que será mais explorado na análise do ato único.

\section{2. $O$ ato único}

Após o prólogo, segue-se o ato único, com o mesmo cenário da reconstituição do salão principal, embora sem o telão branco. Além de escura, agora esta sala encontrase completamente vazia, com marcações de diferentes tamanhos nas paredes, o que indica a ausência dos quadros, que já haviam sido retirados. Para completar o cenário são utilizados sacos de areia espalhados, formando uma barricada, além de uma grande mesa do século XVI.

Nesta peça escrita em 1956, os personagens saem dos quadros para dialogarem e atuarem sobre o passado e o presente da Espanha. Para tanto, muitas de suas falas são frases que Goya escreveu nos seus desenhos e águas-fortes, criando cenas em que eles discutem a situação da Espanha em 1936 e 1808. Assim, o conflito de 36 é construído como um novo episódio que atualiza o da Guerra da Independência, ou seja, ocorre a superposição da Guerra Civil Espanhola (1936) à Guerra da Independência (1808), como aponta Salvador: 
El proyecto que mueve toda esta trama de intertextualidades entre teatro y pintura, tiene su origen en un pasado vital, en este caso, el protagonismo desempeñado por Alberti en la salvación del legado plástico durante la Guerra Civil [...] Todo el sistema épico se construye a partir de dos episodios paralelos, que conforman -a su vez- una superposición temporal. De una parte, "el aguafuerte" goyesco remitiendo a la Guerra de la Independencia y a las circunstancias sociopolíticas del momento y de otra la custodia que el autor y los dos milicianos ejercen en noviembre de 1936 sobre los tesoros del Museo [...] Y el paralelismo entre la epopeya de la Independencia y la epopeya frente al fascismo no es sólo fruto de la preocupación socioplástica del autor, sino que responde a un inconsciente más general, sobre todo en la época de la Guerra Civil. $^{91}$

O desenvolvimento dos dois eventos históricos constitui o ato único, que se divide em nove cenas $^{92}$. Estas se organizam em uma estrutura triádica, ou seja, distribuem-se em três planos que se alternam, com paralelismos temporais, pois os planos não tratam do mesmo período de tempo.

primeiro plano ${ }^{93}$, que possui quatro cenas, corresponde aos personagens extraídos das obras de Goya sobre a Guerra da Independência; o segundo, que é formado por três cenas, desenvolve o tema dos quadros dos pintores Tiziano, Velázquez e Fra Angélico e o terceiro plano, que é constituído de duas cenas, mostra a intervenção dos milicianos no salvamento das obras do museu.

Em relação à sobreposição temporal, o primeiro plano apresenta o enredo principal, com os personagens dos quadros de Goya, tratando portanto dos personagens da Guerra da Independência (1808). O segundo plano ${ }^{94}$ mistura o tempo

\footnotetext{
${ }^{91}$ SALVADOR, Álvaro. Noche de guerra en el Museo del Prado. Cuadernos Hispanoamericanos, Madrid, $\mathrm{n}^{\circ}$ 485486, p. 332, nov./dic. de 1990.

${ }^{92}$ Isto ocorre na edição de 1956, base desta análise, produzida no exílio na Argentina. A edição madrilena de 1975 apresenta uma cena a mais, que trata dos milicianos, no entanto possui frases suprimidas pela censura da época.

${ }^{93}$ Nesta dissertação os planos serão designados de acordo com a ordem de quantidade de cenas.

${ }^{94}$ Em sua introdução à edição de 2008, de Noche de guerra en el Museo del Prado, Torres Nebrera explica que no quadro de Tiziano, Marte rompe a harmonia do amor humano, oferecida desde sua mais perfeita expressão do mito, presidido por uma intensa luminosidade e por um lirismo. Assim, na conversa entre os arcanjos se percebe outra denúncia, a relativa ao desequilíbrio que amordaça toda mensagem de amor e de esperança para o homem. Este se vê reduzido à precariedade de um Adônis, caçador sem armas, e de um arcanjo que tem as asas quebradas e sem a
} 
histórico —o anão, do século XVII- com o tempo mítico traduzido por arcanjos e deuses. O terceiro plano trata de personagens do passado mais recente, ou seja, os milicianos defensores das obras do Prado no mês de julho de 1936, quando o museu foi bombardeado durante a Guerra Civil Espanhola.

Torres Nebrera ${ }^{95}$ explica que nessa peça os mitos são utilizados na exposição de duas mitologias, uma pagã —Vênus e Adônis— e outra cristã: o arcanjo Gabriel e a Virgem Maria. Os dois possuem um ponto em comum, o amor interrompido. Em ambos a guerra coloca-se como empecilho ao amor.

Assim, os amantes Vênus e Adônis são separados por Marte, o deus da guerra. A cena encerra-se com o lamento de Vênus de que a guerra venceu a juventude do mundo:

Adonis (expirando, junto a Venus arrodillada). — ¡Venus! ¡Oh Venus! (El dios Marte, despojado de la piel y máscara de jabalí, se yergue victorioso tras los dos amantes.) Venus (llorando, abrazada al cuerpo de Adonis). - Ha muerto la juventud del mundo, el aroma de los jardines, la primavera de los campos. ¡La guerra! Ahora vendrá la guerra. ¡La sangre! ¡La muerte! Nada más. ¡Adonis! ¡Mi Adonis! (La luz ha disminuido totalmente, quedando la escena en una tiniebla profunda. Silencio.) (p. 33)

lembrança de sua mensagem, adquirindo a condição de exilado, desterrado do céu e de sua memória. Assim, a guerra apresenta como vencidos os dois mitos, o do mundo pagão e o do cristão, expressões do amor, divino e humano, mitos da História da Espanha. TORRES NEBRERA, Gregorio. Introdução. In: ALBERTI, Rafael. Noche de guerra en el Museo del Prado; El hombre deshabitado. Introdução, nota e edição de Gregorio Torres Nebrera. Madrid: Biblioteca Nueba, 2008, p. 48-49.

95 TORRES NEBRERA, Gregorio. Alberti: del teatro político al teatro integrador. Cuadernos Hispanoamericanos, Madrid, nº 485-486, p.258, nov./dic. de 1990. 
O arcanjo Gabriel, com as asas e as palavras quebradas, é impedido de dar a

boa nova à Virgem Maria, a mensagem que a prepararia para a vinda do menino Jesus, gerando o amor materno:

[...] Un rayo de clara luz ilumina el primer término de la escena. Por el lateral derecho entra, Ilorando, túnica rosa pálido, el Arcángel San Gabriel. Trae un ala quebrada.)

Gabriel —La perdí, la perdí... Desapareció de mis ojos cuando iba a decirle mi mensaje. [...] Pero una gran tormenta y una espera tiniebla que lo oscureció todo, me dejaron cortadas las palabras... ¡Dios te salve, María!... ¿En dónde estás, señora? ¿Adónde ir a buscarte, Yo, pobre paloma extraviada, con un ala partida y sin arrullo, quebrado el hilo de la memoria? ¿Cómo seguía el divino mensaje? [...]

Miguel (deteniéndose) -Gabriel. (Avanza hasta posarle su mano en la cabeza.) Alza la frente, amigo. ¿Por qué esas lágrimas? Respóndeme.

Gabriel —Porque no tengo ahora en quien depositar mi mensaje.[...]

Gabriel -El no poder volar quizás ya nunca y tener que quedarme en prisionero en esta tierra de demonios. (Le muestra la mano ensangrentada.) Mira. [...]

Miguel - Las legiones del mal andan de nuevo sueltas por el mundo. Hasta esta tierra en paz han traído el estrago. Pero no temas. Mi espada te defiende.

Vamos. (p. 62-64)

\section{De acordo com Salvador:}

[...] en realidad la estructura de este acto es triangular, no en vano consta de nueve escenas que se van superponiendo como tríos de haces estructurales hasta construir una pirámide. En la base de la misma podríamos situar las cuatro escenas del aguafuerte que aparecen en el siguiente orden: $1^{\underline{a}}, 3^{a}, 6^{\underline{a}}$ y 9a. Inmediatamente encima, constituyendo el primer cuerpo de la pirámide, las tres escenas en las que se desarrollan otros tantos cuadros, $2^{\mathrm{a}}, 5^{\mathrm{a}}$ y $7^{\mathrm{a}}$, y como segundo cuerpo, las dos escenas de los milicianos, $4^{\underline{a}}$ y $8^{a}$. Arriba, en el vértice, coronando la construcción y, simultáneamente fuera de ella, el 'Prólogo"'. ${ }^{96}$

${ }^{96}$ SALVADOR, Álvaro. Noche de guerra en el Museo del Prado. Cuadernos Hispanoamericanos, Madrid, $\mathrm{n}^{\mathrm{o}} 485$ 486, p. 333, nov./dic. de 1990. 
Para melhor visualizar o que propõe Salvador, apresentamos um diagrama com a distribuição das cenas na estrutura dessa peça, como se pode observar na Figura 1:

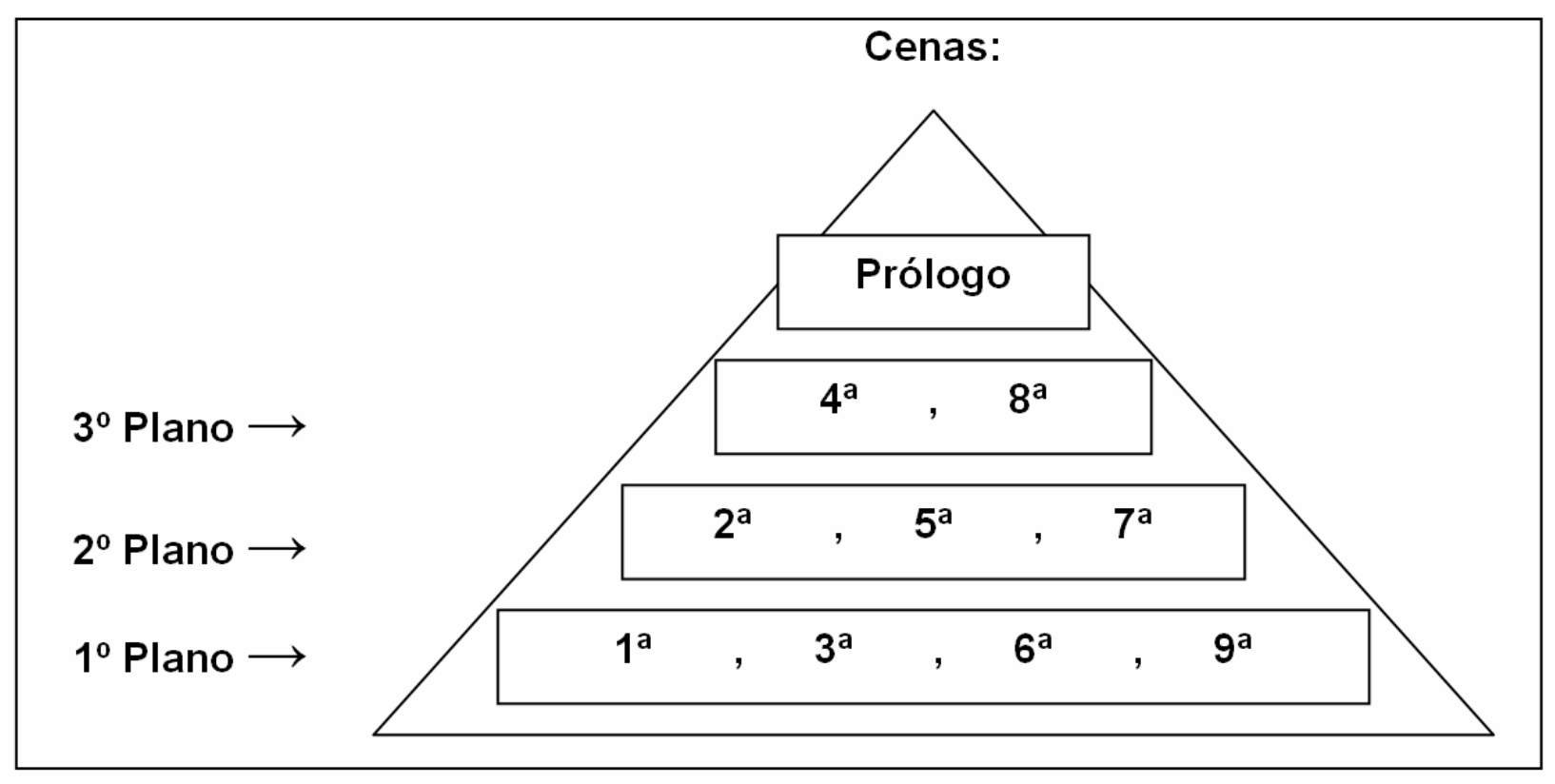

Figura 1 - Distribuição das cenas na peça

A estória principal, primeiro plano, trata dos personagens advindos dos quadros de Goya, do povo e dos aleijados de Madri, representando a Guerra da Independência. Os demais personagens que derivam de quadros, os do segundo plano, resgatam os mitos que retratam a guerra acabando com o amor, além da função de ridicularizar o rei e o anão. Já os milicianos, personagens do terceiro plano, tratam da salvação dos quadros do Museu do Prado, o que é adiantado e preparado pelo prólogo.

Além de suspender temporariamente o enredo principal, sou seja, o primeiro plano, a sequência de cenas, composta pela alternância de planos, rompe o tempo cronológico da peça e a relação de causa e efeito. 
Na estrutura épica, ao mesmo tempo em que se cria a não identificação entre o público e a peça, ocorre também a construção da reflexão do leitor/espectador. Nessa engrenagem, o uso do coletivo, representado pelos personagens populares, desempenha uma função importante, que será melhor explicada no tópico seguinte.

\subsection{O povo}

Do conjunto de personagens, o primeiro que se apresenta é o próprio autor, ou melhor, o narrador-autor. Há também os que saem das obras do Prado: os dos desenhos e águas-fortes de Goya, ou seja, o maneta, o fuzilado, o amolador, o estudante, a "maja", o toureiro, o frade, o cego, as velhas 1, 2 e 3, o decapitado, o burro, o bode, a procissão de aleijados e o povo de Madri; três personagens de um quadro de Tiziano, que são Vênus, Adônis e Marte; dois dos quadros de Velázquez — anão e rei- um da obra de Fra Angélico —Arcanjo São Gabriel— e outro de um retábulo anônimo encontrado em Arguis —Arcanjo São Miguel. Finalmente, há os milicianos 1 e 2, que pertencem ao passado mais recente.

Com exceção dos milicianos 1 e 2, que não saem dos quadros, os demais personagens dessa peça ganham vida durante uma época em que Madri se encontra sitiada, o que está representado no cenário pela barricada, funcionando como uma espécie de escudo para que possam se defender dos invasores externos. Aqui se reconhece a presença da singularidade histórica, um fator épico utilizado a partir do pré-romantismo ocidental, composta pelo cenário de guerra, o salvamento dos quadros do Museu, o povo de Madri, a corte espanhola e a invasão estrangeira. 
Além disso, em Noche de guerra en el Museo del Prado, o narrador-autor faz comentários que caracterizam as vestimentas dos personagens, como por exemplo no caso dos saídos dos quadros de Goya, vestidos com trajes do começo do século XIX: "unos, en colores vivos, pero opacos, y otros en grises, sepias, blancos y negros, buscando el claroscuro de los dibujos y aguafuertes" (p. 5). O figurino desses personagens do passado constitui um fator de separação, de distanciamento entre eles e o público da peça.

Outro detalhe de composição é revelado pelo narrador-autor já no início da peça: as frases pronunciadas pelos personagens na obra. Em sua maioria, são as mesmas que Goya utilizou abaixo de seus desenhos ou águas-fortes. Trata-se do uso da paródia, o que ajuda a confirmar que o enredo do passado mais recente da peça está relacionado à ação mais pretérita.

$\mathrm{Na}$ peça os personagens representam pessoas comuns, do povo, sem nomes próprios, como o maneta, o fuzilado, o amolador, o estudante, o toureiro, o cego, o burro e o decapitado. Alguns são apenas números, como as velhas 1, 2, 3 e os milicianos 1 e 2. Trata-se de um procedimento similar ao utilizado por Bertolt Brecht nas peças didáticas, escritas em $1929^{97}$.

A explicação para tal ocorrência é que a peça está estruturada sob a ótica do coletivo, na qual todos são semelhantes, outra marca épica. Alguns personagens não possuem nomes próprios e outros nem sequer números, como no caso do povo de Madri e da procissão de aleijados, agrupados totalmente sob designação do coletivo.

\footnotetext{
${ }^{97}$ Em "Aquele que diz sim, aquele que diz não" os personagens são os três estudantes, a mãe, o professor e o menino; em "A Peça Didática de Baden-Baden sobre o acordo" os personagens são os três mecânicos, o líder do coro, o narrador, o aviador, os três palhaços — primeiro, segundo e terceiro- e o coro, ou seja, são definidos por nomes comuns ou numerais. Cf. BRECHT, Bertolt. Aquele que diz sim, aquele que diz não; A peça didática de Baden-Baden sobre o acordo. In: Teatro Completo. Vol. V. Rio de Janeiro: Paz e Terra, 1992.
} 
Embora tenham saído de quadros de pintores citados na obra, os personagens cumprem a função de representar não reis ou cavaleiros com seus grandiosos feitos heroicos, mas sim pessoas do povo. São homens originários da classe baixa: os derrotados, massacrados e humilhados de 1808. No entanto, na peça, é afirmado que eles não morrem nunca e não se deixam abater. Apesar de tudo que Ihes passa, não podem ceder espaço à tristeza, devem manter o sorriso no rosto, na luta popular pela conquista da liberdade

Alguns desses personagens fazem uso de máscaras, elementos de função alegórica, que caracterizam e distanciam os personagens da realidade do público. Além de ser antirrealista, elas escondem as expressões faciais dos atores, criando o efeito similar a uma leitura interpretativa de texto em voz alta no palco. Assim, cumprem a função de caricatura, elemento do campo do grotesco, que contribui para não haver aproximação entre atores e personagens, ou seja, para que não ocorra uma completa atuação e sim uma ilustração da narração, de modo a gerar o efeito de distanciamento. Isso se reforça tanto com a presença de figuras de quadros do museu que retratam o passado, narrando a Guerra da Independência, como pela existência de personagens mais irônicos e grotescos como as velhas 1, 2, 3, o descabeçado, o rei e o anão.

As velhas 1 e 2 representam as damas da rainha, que na peça defendem a corte e tentam transferir a responsabilidade da decadência da Espanha para a invasão estrangeira, principalmente a francesa, simbolizada por Napoleão, o qual elas chamam de "Napoladrón". Ao contrário das velhas, os demais personagens não centralizam a culpa nos franceses, mas sim na família real espanhola.

Há um rei ridicularizado, embora derivado do quadro de Velázquez, veste-se como no Disparate n‥ 2 de Goya, com o roupão e o capus escuros de espantalho e a 
legenda "Locura del miedo", que contracena com um anão, do quadro $D$. Sebastián de Morra. Assim, para retratar o rei Felipe IV, o autor deu mais ênfase a este quadro de Goya, que pinta um rei fraco e patético, do que à pintura de Velázquez ${ }^{98}$. O fato de estar com a companhia de um anão que se veste da mesma forma que $D$. Sebastián de Morra no retrato, como afirma o narrador no início da peça, revela uma estratégia que pode resultar no efeito de humor, ironia, estranhamento e distanciamento. Isto ocorre a partir da interferência direta do narrador-autor, com a ajuda dos demais personagens, que fazem uso de frases curtas, ridicularizações e acusações ao rei e seus convivas.

Na cena final, o rei, agora representado por Carlos IV, é mostrado como parasita do povo, vestido de bode, a rainha María Luisa é apresentada como a grande prostituta, vestida de velha 3, e seu amante -Don Manuel Godoy, disfarçado de sapo, é confundido com Napoleão, ambos na representação da família real ${ }^{99}$. Sendo assim, em substituição a Napoleão e os franceses, Godoy aparece aqui como o verdadeiro inimigo do povo.

Representante de uma Espanha corrupta, assim como Carlos IV, Don Manuel é visto como o traidor de 1808 e também como a representação do general Franco, o usurpador de 1936. Tanto Manuel Godoy como o general Franco recebeu em sua época o rótulo de "generalísimo". As frases pronunciadas pelo personagem maneta no desfecho da peça possuem um duplo e ambíguo direcionamento, tanto a Godoy, como a Franco:

\footnotetext{
${ }^{98}$ Retrato de Felipe IV en traje de caza, de Diego Velázquez.

${ }^{99}$ No início do século XIX o rei Carlos IV de Borbón e a rainha María Luisa estavam em seu reinado e Manuel Godoy, conhecido como Generalíssimo, era o primeiro ministro, responsável por uma política aliada e obediente a Napoleão. Com a abdicação de Carlos IV, Fernando VII assumiu por pouco tempo o trono, sendo deposto pela invasão francesa. Assim, a família real foi exilada e José Bonaparte foi nomeado o novo rei da Espanha em 1808, criando uma crise institucional e econômica. Entre 1808 e 1813 ocorreu a chamada Guerra da Independência, que conseguiu expulsar José Bonaparte do país e devolver o trono espanhol para a Corte de Borbón.
} 
¿Quién era ese que pretendía ceñirse la corona de nuestros Reyes y se colgó a sí mismo los nobles rótulos de Generalísimo y Príncipe de la Paz? Un violador de esa misma paz, un ambicioso cómplice del más odiado destructor de pueblos, derramador de infinita sangre... ¿Y qué sucede ahora? Pues que otra vez tenemos a su hipócrita amigo, a su insaciable dueño, el verdadero sapo - ese buitre carnívoro- llamando con la muerte a los heroicos muros de nuestra capital española [...] Colguemos cuanto antes de lo alto a esos podridos símbolos de la desvergüenza y de la tiranía. (p. 77)

Esta peça resgata para a cena os populares. Os vilões são julgados pelo povo de Madri e pelas vítimas da guerra, sendo condenados à morte. Ao mesmo tempo em que usa uma máscara de bode, o rei é morto pelo toureiro como um animal, um touro, e a rainha e seu amante são enforcados, causando a comemoração popular.

Com o julgamento, a condenação e a execução dos culpados, os horrores da guerra são passados a limpo, com o teatro colocando-se ao lado do povo no combate, criando uma reflexão para que os leitores/espectadores sigam o exemplo e saiam às ruas, com as armas que tiverem, para lutar contra quem represente uma ameaça ao patrimônio artístico e à democracia.

Assim, é relevante o perfil dos personagens, já que eles representam pessoas comuns e, por isso, o coletivo pode fazer valer a sua força. Ao mesmo tempo em que o poder emana do povo, a realeza é ridicularizada, criando uma polarização e uma série de contrastes. 


\subsection{Os contrastes}

A peça trabalha com dois pólos, o positivo e o negativo. O positivo indica o equilíbrio, a Espanha que as pessoas querem ou desejam para si. O negativo indica o contrário, o desequilíbrio, a Espanha que as pessoas não querem ou não desejam para si. As bombas, os disparos, as atrocidades, as vítimas da guerra e as ameaças ao patrimônio histórico nacional estão no lado negativo. A paz, o amor, a busca pela liberdade e a defesa do patrimônio histórico estão no lado positivo.

Segundo Torres Nebrera, em sua introdução à edição de 2008 de Noche de guerra... ${ }^{100}$, nesta obra há uma luta entre esses dois opostos, que se estrutura desde 0 título, pois "Noche de guerra" representa o lado negativo e "Museo del Prado" representa o lado positivo. Esta dicotomia também se estende aos quadros apresentados na peça. O quadro Las tres gracias, de Rubens, sugere a harmonia e a alegria, já a mensagem de Garcilaso que acompanha o pé do quadro sugere a violência e a desarmonia. Da mesma forma, se contrastarmos Las tres gracias com Los fusilamientos del 3 de mayo, podemos perceber que o equilíbrio que estava presente no primeiro quadro rompe-se no segundo com a presença de seres angustiados. Outros quadros de Goya como La asamblea de las brujas, Desastres de la guerra ou a pintura negra La peregrinación de San Isidoro também sugerem essa desarmonia.

Os arcanjos também representam uma oposição. Enquanto Gabriel é o mensageiro da paz, Miguel é o anjo guerreiro que luta contra Lúcifer e o seu exército de

${ }^{100}$ TORRES NEBRERA, Gregorio. Introdução. In. ALBERTI, Rafael. Noche de guerra en el Museo del Prado; El hombre deshabitado. Introdução, nota e edição de Gregorio Torres Nebrera. Madrid: Biblioteca Nueba, 2008, p. 3439. 
obscuridades, representado pelas pinturas negras, ou seja, o fim do amor e da paz, o acirramento da violência ${ }^{101}$.

Em Noche de Guerra..., do lado negativo estão a noite, a escuridão, a guerra, a violência, o fim do amor, o cenário vazio —representado pela ausência dos quadros, a morte, a barbárie, a desgraça e a destruição. Já do lado positivo estão o fim da guerra e a execução dos culpados, simbolizado também pela luz, com a chegada do dia, no desfecho da peça.

A guerra corresponde às imagens demoníacas, definidas por Frye ${ }^{102}$, como a representação do mundo que não queremos, do pesadelo, do cativeiro, da dor, da confusão e do bode expiatório, universo encerrado com os massacrados que voltam para acertar as contas com os culpados, dentro de um museu escuro e esvaziado.

Aplicando nesta peça os conceitos de Frye $^{103}$, a sala sinistra do museu abandonado na Madri sitiada, o subsolo do Prado, espécie de calabouço sem luz onde se aprisionam os quadros, as armas de guerra e as forcas simbolizam o mundo mineral, inorgânico. As explosões simbolizam o mundo do fogo, o sangue derramado evoca o sacrifício e as bruxas, inclusive associadas a uma rameira como é pintada a velha 3 , simbolizam a imagem erótica demoníaca.

Apesar de pobres e massacrados, os personagens não perdem o orgulho, tanto que discutem, divergem entre si, mas sempre mantendo o mesmo objetivo de luta. É a representação da sociedade madrilena, pois, a população desta peça é uma sociedade rebaixada, uma imitação da vida real e um universo demoníaco.

\footnotetext{
101 TORRES NEBRERA, Gregorio. Introdução. In. ALBERTI, Rafael. Noche de guerra en el Museo del Prado; El hombre deshabitado. Introdução, nota e edição de Gregorio Torres Nebrera. Madrid: Biblioteca Nueba, 2008, p. 34.

${ }^{102}$ FRYE, Northrop. Anatomia da crítica. Tradução de Péricles Eugênio da Silva Ramos. São Paulo: Cultrix, 1973, p.148-151.

${ }^{103}$ Idem.
} 
O desfile de personagens como o fuzilado e o descabeçado, gritando com sua cabeça na mão, além de diversas outras ações grotescas, é uma das imagens que compõe o pesadelo humano, o inferno construído na peça, que termina com a morte do rei, da rainha e de seu amante, os bodes expiatórios, sendo, ao mesmo tempo, tiranos e vítimas sacrificais ${ }^{104}$.

Em "Noche de guerra en el Museo del Prado", ao invés de o povo continuar sendo a vítima sacrificada pelos erros dos governantes, a situação inverte-se, pois os populares lutam para que este momento seja a hora de a família real sofrer e o vilão tomar o lugar da vítima no sofrimento, com o rei sendo julgado, condenado e sacrificado no final:

\begin{abstract}
Voces - !A la horca! !A la horca!
Fusilado -El pueblo, una mañana, se levantó sin rey, vendido, rodeado de extranjeros invasores, abandonado a sus propias fuerzas. Ésos, y otros como ésos, los que desde un palacio se comían nuestra sangre y nos juraban ser nuestros leales protectores, corrieron a ponerse de rodillas a los pies de nuestro verdugo. Pido también la horca como castigo. Os habló un fusilado del mariscal Murat.

Voces - !Mueran! !Mueran!

Maja (con dignidad y burla, haciendo una reverencia ante el pelele de la reina). -Dignísima señora: !Buen viaje! No sólo muere el pueblo. No va a ser vuestra muerte de herida limpia de navaja o de disparo de arcabuz. Eso es para nosotros, el populacho. Vos, digna Majestad, vos, Alteza, seréis colgados alto como merecen vuestras altísimas alcurnias. (p. 71-72)
\end{abstract}

Esta leitura de Noche de guerra... também destaca como os elementos épicos na estrutura da peça são bastante significativos, o que será apresentado no tópico a seguir.

\footnotetext{
${ }^{104}$ Segundo Frye, "no mundo humano sinistro um pólo individual é o chefe tirânico [...] O outro pólo é representado pelo pharmakós, ou vítima sacrifical, que tem que ser morta para fortalecer os outros. Na modalidade mais concentrada da paródia demoníaca, os dois se tornam o mesmo". FRYE, Northrop. Anatomia da crítica. Tradução de Péricles Eugênio da Silva Ramos. São Paulo: Cultrix, 1973, p. 149.
} 


\subsection{O teatro épico}

Como já comentado, esta peça parte de um acontecimento real, em que os milicianos descem os quadros aos porões do Museu do Prado para que fiquem mais protegidos dos bombardeios em novembro de 1936, acontecimento que Alberti apresenta em paralelo a outra situação de resistência popular, a de maio de 1808 , contra as tropas napoleônicas, retratada por Goya em desenhos e águas-fortes.

Enquanto no grego "drama" significa "ação", nessa peça a análise e a reflexão dos personagens sobrepõem-se à ação pura, o que caracteriza o drama moderno. Como o foco não é colocado no material de ação e sim no material analítico, ocorre uma "epicização" do drama, pois o texto épico constrói o distanciamento como forma de produzir o raciocínio e a reflexão na plateia.

O narrador-autor está nos bastidores, decidindo como narrar a História. Além disso, ele se dirige diretamente ao público para dar boa noite, o que quebra desde o início a ilusão clássica, gerando um distanciamento, que inibe a identificação entre personagem e público, fazendo com que os leitores/espectadores desenvolvam a visão crítica.

Outros procedimentos que contribuem para a não-identificação são as quebras de som e de luz constantes, que não permitem que os personagens de Goya e o público da peça se dispersem de seus objetivos coletivos, ou melhor, da causa urgente de passar a limpo o passado da Espanha e de abordar a guerra, materializada em cena por estrondos. Nos momentos em que os personagens começam a levar a discussão para suas diferenças, os ruídos de guerra interrompem o diálogo. Esses signos acústicos, de metralhadoras, explosões de bombas, disparos de armas e canhões, 
sobrevôos de aviões, adquirem também a função de chamar a atenção para a presença do agente externo, o agressor.

A falta de iluminação também serve para marcar as mudanças de cenas, o que ocorre na entrada e na saída de personagens com a luz focalizada em quem fala. Desta forma, o foco de luz cumpre no ato único uma função similar àquela do narrador no prólogo, de iluminar e fixar a atenção em determinado personagem, direcionando a visão do público, além de marcar que se trata de uma noite.

Assim, na junção das duas quebras, de som e iluminação, a noite de guerra está sempre presente na peça. Como somente os personagens que falam são focados pela luz, as mudanças de cenas ficam mais sutis, ou seja, não se percebe a troca de personagens e de planos visualmente. Ela se dá pela mudança de vozes e do tema tratado entre uma cena e outra, já que o cenário não muda na troca de cenas e é constituído pela penumbra.

Em complemento a tais recursos, está o riso do povo, que serve para ridicularizar e distanciar os governantes, deixando de lado as formas da tragédia para contar a História da Espanha. Com isso, o autor opta pelo épico com pinceladas de comédia.

Considerando que as origens gregas da tragédia estão associadas às histórias dos homens superiores, como reis e governantes, ao contrário da comédia, relacionada às histórias dos homens inferiores, do povo, nota-se que nesta peça há uma inversão. Assim, o cômico surge para dar forma à destituição dos governantes de seu poder no país. É uma espécie de revolução popular, na qual os pobres rebaixam seus governantes a um nível bastante inferior. A revolução completa-se com o julgamento da família real resultando nas condenações à morte, como ocorre no final desta peça. 
O uso do cômico também contribui para construir o distanciamento entre 0 público e a peça, elemento necessário para que ocorra o processo de análise no público, pondo em debate o sofrimento do povo espanhol no período que compreende desde a Guerra da Independência até a Guerra Civil.

\subsection{Considerações sobre Noche de guerra en el Museo del Prado}

As duas guerras são dramaticamente identificadas como uma mesma: a do povo espanhol sitiado, revoltado com a traição e a injustiça da qual é vítima, contra os abusos dos seus opressores. De novo as pessoas simples estão preparadas para morrer com heroísmo, combatendo as mesmas causas, as invasões do inimigo estrangeiro e o traidor da pátria —Napoleão e seu colaborador Godoy, Hitler, Mussolini e seu aliado Franco.

Os heróis da resistência do século XIX contra as tropas napoleônicas são também os novos heróis da resistência contra as tropas comandadas por Franco, com a particularidade de que o tempo do drama não é só o passado remoto nem o passado recente, mas o presente histórico, ao mesmo tempo superação e integração como expressões dramáticas de uma mesma realidade ${ }^{105}$.

A representação do Museu do Prado é a representação da própria Espanha. Seus quadros contam sua História, com seus personagens mutilados e fuzilados, que representam o povo maltratado e massacrado pela guerra.

Noche de guerra en el Museo del Prado se vincula à grande pintura espanhola e europeia no seu livro A la pintura, nunca esquecida por Alberti, sendo, aliás, para o

${ }^{105}$ RUIZ RAMÓN, Francisco. Historia del teatro español. Siglo XX, Madrid: Cátedra, 1995, p. 217. 
poeta no exílio, uma das mais fortes visões da Espanha então dominada e uma forma de denúncia.

Nesta peça, a fraqueza da coroa espanhola é responsabilizada, tanto pela invasão napoleônica no século XIX, como pelo golpe de Franco no século XX. Sobre a figura do rei, por sua fraqueza e omissão, recai a culpa da tragédia da Espanha.

Por outro lado, os personagens são sempre estimulados com expressões do tipo "el pueblo nunca muere" ou "nunca ha de morir", representando sua disposição na luta com as armas que tiverem, exemplificado pelo descabeçado, que embora não possua armas, utiliza seu próprio corpo, lançando sua cabeça como uma granada e caindo em seguida. Esta cena possui um paralelo com a Guerra Civil Espanhola, quando o povo se armou com o que tinha em mãos.

A morte do rei, da rainha e seu amante representam um acerto de contas com a família real, como uma revolução proletária em defesa de seu patrimônio artístico, já que, caso os quadros fossem destruídos, jamais seriam recuperados. A luz só retorna totalmente quando a noite acaba e o conflito termina, ou seja, com o julgamento e a execução da família real pelas vítimas da guerra, os aleijados e o povo de Madri. Nesse momento os vidros estilhaçam-se, representando o fim de um ciclo. Com esse desfecho a noite acaba e faz-se a luz, clareando o dia.

O problema da guerra resolve-se na peça, o que não ocorre na vida real. Assim, a peça dá exemplo de como o povo poderia agir, fazendo justiça, abrindo os olhos da população e resolvendo na ficção o que na realidade da Espanha em 1936 se deu de outro modo.

A presença do narrador épico, o efeito de distanciamento e o convite à reflexão são os principais fatores que dão à peça o seu caráter épico. Entretanto, embora 
possua essas características, o texto não se inspira diretamente no teatro asiático, como Brecht, mas sim nos problemas da Espanha, como a Guerra Civil Espanhola, os bombardeios a Madri, as atitudes da família real, o salvamento dos quadros e o Museu do Prado.

De acordo com Torres Nebrera ${ }^{106}$, Noche de guerra en el Museo del Prado é um ponto de chegada e o lugar de encontro dos componentes teatrais como 0 distanciamento épico e a ótica esperpêntica ${ }^{107}$ no tratamento dos personagens e das situações, os quais Alberti já havia utilizado em peças anteriores. Os Mitos, o distanciamento histórico, o compromisso vigente e atualizado, a plasticidade cênica, o epicismo e esperpentismo e a nostalgia de um paraíso perdido associam muitos recursos já testados anteriormente pelo autor.

Por outro lado, a pintura é a matéria prima para Noche de guerra en el Museo del Prado. No entanto, nesse texto, ela não é nada estática, pois luta contra uma grande barbárie. Aqui a arte não é apresentada como cultura de elite. Pelo contrário, povo e arte estão em simbiose, já que a pintura e os mitos agem ao lado dos espanhóis, da mesma forma que estes, representados pelos milicianos e pelos personagens que saem dos quadros, também defendem a pintura.

Assim, os mitos perdem os sentidos, representando o esvaziamento, tanto da religião ${ }^{108}$ —arcanjo Gabriel, como também da concepção burguesa de arte —Vênus e

\footnotetext{
106 TORRES NEBRERA, Gregorio. Alberti: del teatro político al teatro integrador. Cuadernos Hispanoamericanos, Madrid, n 485-486, p.258-259, nov./dic. de 1990.

107 Ver nota 76 desta dissertação.

${ }^{108}$ A igreja também não é poupada nesta peça, como no exemplo do irônico personagem do frade. De acordo com Monleón, o juizo político de Alberti aponta características antirreligiosas -anticatólicas- em El hombre deshabitado e antifascistas em Noche de guerra... Assim, "Noche de guerra en el Museo del Prado es, a partir de una anécdota real - los riesgos del Museo bajo los bombardeos de la Guerra Civil, la acumulación de los cuadros en los espacios menos vulnerables y la evacuación a Valencia de los más valiosos-, una dramatización de ese sentimiento conservado y crecido en la memoria de Alberti desde sus años de juventud: los cuadros del Museo eran los 'azules
} 
Adônis ${ }^{109}$. Segundo Crispin ${ }^{110}$, "[...] en Noche de guerra... Alberti, con potente fuerza y lograda unidad dramática, reivindica el concepto marxista del arte al servicio del pueblo y de la revolución [...]"

Desta forma, a peça vai além de apenas contar a História da Espanha e de seu povo. Ela busca politizar, mobilizar o leitor/espectador contra o franquismo ${ }^{111}$, já que, quando tal obra foi produzida na Argentina, a Espanha ainda estava sob um regime ditatorial, fruto do golpe militar, e o autor, exilado.

Para tal propósito o teatro épico se mostra bastante eficiente, pois 0 distanciamento dá à peça uma função didática, que servirá de exemplo aos espanhóis, ou a qualquer outra população, para que, toda vez que tiverem suas liberdades usurpadas, tomem a atitude de ir à luta.

del cielo'; los aviones de bombardeo, la tiniebla, la religión, el fascismo.” MONLEÓN, José. Teatro e infancia de Rafael Alberti. Cuadernos Hispanoamericanos, Madrid, n 485-486, p.239, nov./dic. de 1990.

109 "Venus se queja de que por la guerra 'ha muerto la juventud del mundo, el aroma de los jardines, la primavera de los campos' [...] Pero Venus, como símbolo tradicional de la belleza ideal, es incapaz de ver la virtud sacrificatoria de esta guerra. La cita indica que lo que muere para ella es un mundo idílico idealizado por el arte [...] Venus y Adonis son personajes que no pueden sobrevivir: deben desaparecer como símbolos de una concepción burguesa del arte. La función de los arcángeles es aún más clara según se interpreta dentro del mito de la rendición marxista. Gabriel era un mensajero de la redención cristiana. [...] Ciertamente, Gabriel no se acuerda de su mensaje porque éste ya no tiene significación. Es portador de un mito ilusorio, o al menos, caducado y por eso San Gabriel aparece aquí, junto con San Miguel, como desorientado e impotente. El nuevo redentor es el pueblo, cansado ya de oír la falsa promesa de la religión". CRISPIN, John. Los tres paraísos: religioso, estético y marxista en Noche de guerra en el Museo del Prado. Insula, Madrid, no 40 (467), p. 3, oct. de 1985.

${ }^{110}$ Idem.

${ }^{111}$ Referente aos defensores do golpe militar do General Franco. 


\section{CONSIDERAÇÕES FINAIS}


Durante o exílio, além de uma grande fonte de inspiração para o escritor Rafael Alberti, o Museu do Prado é um local de forte ligação do autor com sua pátria distante. Duas grandes obras de Alberti, escritas nessa época, possuem o Prado como tema central: o livro de poemas A la pintura e a peça de teatro Noche de guerra en el Museo del Prado.

As obras possuem vários pontos em comum. Em ambas há uma introdução e, em seguida, uma estrutura triádica. A la pintura possui o poema introdutório "1917" e, na sequência, apresenta três tipos de poemas mesclados: sobre as cores, os pintores e os elementos da pintura. Já em Noche de guerra en el Museo del Prado, o prólogo cumpre a função introdutória, com a atuação alternada de três planos no desenvolvimento do ato único, assim como os três tipos de poemas no livro $A$ la pintura.

Em relação à temática, os dois livros possuem o Prado como cenário e apresentam a pintura como eixo, com diversos quadros e pintores semelhantes. Goya por exemplo, a quem é dedicado um poema em $A$ la pintura, ganha bastante destaque na peça teatral, através de suas pinturas e seus personagens. No caso de Picasso, o grande homenageado do primeiro livro, está indiretamente presente na peça, já que era o diretor do Museu do Prado na época do episódio do salvamento das obras que inspirou a peça. Outros pintores, como Fra Angélico, também estão presentes nos dois livros.

Além disso, ambos os livros fazem referência direta ou indireta aos mesmos quadros do Museu, como Las tres gracias, a série Los fusilamientos, além do elemento claro-escuro, presente nos poemas, que se torna a base para Noche de guerra...

Por outro lado, os dois livros possuem algumas diferenças. Se em $A$ la pintura, apesar de aparecer a visão realista da arte na parte final do poema "1917", o conceito 
de arte predominante no restante da obra é o burguês, contemplativo. Já a peça de teatro parte dessa concepção contemplativa de arte no prólogo, com a citação de parte de poema "1917", que representa o conceito de arte pura. Em seguida, no ato único, esta visão é substituída pelo conceito marxista de arte a serviço do povo e da revolução ${ }^{112}$, constituindo, assim, uma inversão em relação ao primeiro livro.

$\mathrm{Na}$ transposição da pintura do poema para o teatro, o que era estático ganha vida, atuação. Segundo Morris:

La obra de Rafael Alberti nos enseña que la creatividad no acata fronteras ni tolera barreras; en ella, poemas e imágenes pasan al teatro para ser llevados a la escena o acompañados de música; los poemas de $A$ la pintura captan la individualidad de muchos pintores; en Noche de guerra en el Museo del Prado, los personajes de ciertos cuadros bajan de sus marcos y hablan $[\ldots]^{113}$

O livro de poemas representa o primeiro passo, de recriar a atmosfera dos pintores e de reconstituir os quadros do museu, já a peça representa a continuação e o avanço ao primeiro. Em relação à pintura, se em $A$ la pintura os quadros eram somente mostrados, em Noche de guerra en el Museo del Prado os personagens dão um passo a frente: deixam de servir apenas para a contemplação burguesa, pois agora saem das molduras e ganham a função de atuar, lutar em defesa do povo.

O Museu do Prado é a casa da pintura para Alberti e a representação da Espanha durante os anos nos quais foi separado de sua terra natal. Assim, os dois livros que retratam o Museu complementam-se, como a visão da Espanha por um exilado em dois capítulos: o da contemplação e o da conscientização.

\footnotetext{
${ }^{112}$ CRISPIN, John. Los tres paraísos: religioso, estético y marxista en Noche de guerra en el Museo del Prado. Insula, Madrid, $\mathrm{n}^{\circ} 40$ (467), p. 3, oct. de 1985.

${ }^{113}$ MORRIS, C. Brian. Alberti en la generación del 27. Cuadernos Hispanoamericanos, Madrid, $\mathrm{n}^{\circ}$ 514-515, p.259, abr./mayo de 1993.
} 


\section{BIBLIOGRAFIA}




\section{Bibliografia de Rafael Alberti}

ALBERTI, Rafael. A la pintura. Poema del color y la línea. [1945-1948]. Buenos Aires: Losada, 1948.

. A la pintura. (Poema del color y la línea. 1945-1976). Madrid: Alianza, 1989.

. La arboleda perdida. Libros I y II de memorias. Barcelona: Seix Barral, 1989.

. La arboleda perdida. Tercero y cuarto libros (1931 - 1987). Madrid: Alianza,

1998.

. La arboleda perdida 3. Quinto libro (1988 - 1996). Madrid: Alianza, 1999.

. Mi última visita al Museo del Prado. In: . Relatos y prosa. Barcelona:

Bruguera, 1980, p. 117-122.

. Noche de guerra en el Museo del Prado. (Aguafuerte, en un prólogo y un acto).

Buenos Aires: Losange, 1956.

. Noche de guerra en el museo del Prado; El hombre deshabitado. Introdução, nota e edição de Gregorio Torres Nebrera. Madrid: Biblioteca Nueva, 2008.

\section{Bibliografia sobre Rafael Alberti}

ALBORNOZ, Aurora de. Por los caminos de Rafael Alberti. Anthropos, ํㅜ 39-40, p. 8084, 1984.

ALEIXANDRE, Vicente. Dos lecturas de Rafael Alberti. Insula, Madrid, no 198, p. 1 e 2, mayo de 1963.

ALONSO, Dámaso. Rafael Alberti entre su arboleda. Insula, Madrid, oㅜ 198, p. 1 e 16, mayo de 1963. 
ÁNGEL VALENTE, José. La necesidad y la musa. Insula, Madrid, oㅡ 198, p. 6, mayo de 1963.

BARRERA LÓPEZ, José María. Alberti en el ultraísmo. Cuadernos Hispanoamericanos, Madrid, № 485-486, p. 95-107, nov./dic. de 1990.

BUSQUETS, Loreto. El arte deshumanizado de Góngora y Alberti. Cuadernos Hispanoamericanos, Madrid, no 485-486, p. 119-135, nov./dic. de 1990.

CARMONA, Eugenio. Pintura y poesía en la generación del 27 (seis aproximaciones). Cuadernos Hispanoamericanos, Madrid, № 514-515, p.103-116, abr./mayo de 1993.

CHICA, Francisco. Litoral: la poética del agua. Cuadernos Hispanoamericanos, Madrid, № 485-486, p. 81-86, nov./dic. de 1990.

COLINAS, Antonio. Rafael Alberti, poeta de la luminosidad latina. Anthropos, № $39-40$, p. $72-77,1984$.

CÓZAR, Rafael de. Andalucía y la generación del 27. Cuadernos Hispanoamericanos, Madrid, no 514-515, p.319-321, abr./mayo de 1993.

CRISPIN, John. Los tres paraísos: religioso, estético y marxista en Noche de guerra en el Museo del Prado. Insula, Madrid, № 40 (467), p. 3, oct. de 1985.

FUNDACIÓN RAFAEL ALBERTI. Rafael Alberti. Disponível em: <http://www.rafaelalberti.es/>. Acesso em: 26 out. 2011.

GARCÍA MONTERO, Luis. Alberti, peligro para caminantes (1925-1939). Anthropos, no 39-40, p. 68-71, 1984.

. Alberti, Poeta del exilio. Cuadernos Hispanoamericanos, Madrid, № 485-486, p.179-188, nov./dic. de 1990.

GARCIA TERRÉS, Jaime. El mar y la mar de Rafael Alberti. Occidente, Madrid, no 109, p. 81-89, jun. de 1990. 
GAYA NUÑO, Juan Antonio. Carta a Rafael Alberti sobre la pintura. Insula, Madrid, no 198, p. 3 e 14, mayo de 1963.

GEIST, Anthony L.. El 27 y la vanguardia: una aproximación ideológica. Cuadernos Hispanoamericanos, Madrid, no 514-515, p.53-64, abr./mayo de 1993.

GOLOBOFF, Gerardo Mario. Argentina en la poesía de Alberti. Cuadernos Hispanoamericanos, Madrid, no 485-486, p. 189-192, nov./dic. de 1990.

GONZÁLEZ MARTíN, J. P. Rafael Alberti, notas bibliográficas sobre Rafael Alberti. Anthropos, ํo 39-40, p. 27-31, 1984.

GONZÁLEZ TROYANO, Alberto. Una nueva sensibilidad ante la fiesta de toros. Cuadernos Hispanoamericanos, Madrid, № 514-515, p.321-323, abr./mayo de 1993.

GONZÁLEZ, Ángel. La poesía de la generación del 27. Cuadernos Hispanoamericanos, Madrid, no 514-515, p.39-51, abr./mayo de 1993.

GULLÓN, Ricardo. Alegrías y sombras de Rafael Alberti. Insula, Madrid, № 198, p. 1 e 5, mayo de 1963.

- De lo vivo a lo pintado: símbolos en la poesía de Alberti. Cuadernos Hispanoamericanos, Madrid, № 485-486, p. 275-284, nov./dic. de 1990.

HENARES, Ignacio. La pintura y la estética en Alberti. Cuadernos Hispanoamericanos, Madrid, no 485-486, p. 193-202, nov./dic. de 1990.

HERNÁNDEZ VALCÁRCEL, Maria del Carmen. La expresión sensorial en cinco poetas del 27. Murcia: Universidad de Murcia. 1978.

JIMÉNEZ MILLÁN, Antonio. El compromiso en la poesía de Alberti (República, guerra, exilio). Cuadernos Hispanoamericanos, Madrid, no 485-486, p. 145-161, nov./dic. de 1990. 
LINARES, Abelardo. A la pintura. Cuadernos Hispanoamericanos, Madrid, № 485-486, p. 304-306, nov./dic. de 1990.

MARICHAL, Juan. Una espléndida década (1926-1936). Cuadernos Hispanoamericanos, Madrid, № 514-515, p.25-37, abr./mayo de 1993.

MARRAST, Robert. La prosa de Alberti. Algunos temas y motivos recurrentes. Cuadernos Hispanoamericanos, Madrid, no 485-486, p. 203-211, nov./dic. de 1990.

MARTÍN, Sabas. Alberti: Teatro abierto. Cuadernos Hispanoamericanos, Madrid, oo 485-486, p. 161-273, nov./dic. de 1990.

MONLEÓN, José. Teatro e infancia de Rafael Alberti. Cuadernos Hispanoamericanos, Madrid, no 485-486, p.231-243, nov./dic. de 1990.

MORRIS, C. Brian. Alberti en la generación del 27. Cuadernos Hispanoamericanos, Madrid, no 514-515, p.251-271, abr./mayo de 1993.

OLIVA, César. El teatro de la generación del 27. Cuadernos Hispanoamericanos, Madrid, no 514-515, p.93-101, abr./mayo de 1993.

POCHAT, María Teresa. Rafael Alberti en la Argentina (1940-1963). Cuadernos Hispanoamericanos, Madrid, № 485-486, p. 25-34, nov./dic. de 1990.

PRADO, Benjamín. De un momento a otro. Cuadernos Hispanoamericanos, Madrid, no 485-486, p. 229-300, nov./dic. de 1990.

Rafael Alberti. Ed. de Manuel Durán. Madrid: Taurus, 1984. (Série el escritor y la crítica).

SABUGO ABRIL, Amancio. Alberti en las revistas literarias del 27. Cuadernos Hispanoamericanos, Madrid, № 485-486, p. 87-94, nov./dic. de 1990.

SALINAS DE MARICHAL, Solita. Los paraísos perdidos de Rafael Alberti, Insula, Madrid, no 198, p. 4 e 10, mayo de 1963. 
SALVADOR, Álvaro. Noche de guerra en el Museo del Prado. Cuadernos Hispanoamericanos, Madrid, no 485-486, p. 331-333, nov./dic. de 1990.

SANTONJA, Gonzalo. Alberti y las publicaciones periódicas "comprometidas" durante los años treinta. Cuadernos Hispanoamericanos, Madrid, № 514-515, p.352-360, abr./mayo de 1993.

SORIA OLMEDO, Andrés. La depuración de la Mirada. En torno al neopopularismo en Rafael Alberti. Cuadernos Hispanoamericanos, Madrid, № 485-486, p. 109-118, nov./dic. de 1990.

TORRES NEGRERA, Gregorio. Alberti: del teatro político al teatro integrador. Cuadernos Hispanoamericanos, Madrid, no 485-486, p.245-259, nov./dic. de 1990.

ZARDOYA, Concha. Poesía y exilio de Alberti. Cuadernos Hispanoamericanos, Madrid, oㅜ 485-486, p. 163-177, nov./dic. de 1990.

ZULETA, Emilia de. Cinco poetas españoles: Salinas, Guillén, Lorca, Alberti, Cernuda. Madrid: Gredos, 1971.

\section{Bibliografia geral}

ALONSO, DÁMASO. Poesia espanhola. Ensaio de métodos e límites estilísticos. Trad. de Darcy Damasceno. Rio de Janeiro: I.N.L., 1960.

ALONSO, Dámaso; Bousoño, Carlos. Seis calas en la expresión literaria española (prosa, poesía, teatro). 4a․ ed. Madrid: Gredos, 1979.

ARGÁN, Giulio Carlo. Arte moderna. Trad. de Denise Bottmann e Federico Carotti. São Paulo: Companhia das Letras, 2008. 
BOUSOÑO, Carlos. Teoria de la expresión poética (hacia una explicación del fenómeno lírico a traves de textos españoles). Madrid: Gredos, 1952.

BRECHT, Bertolt. Aquele que diz sim, aquele que diz não; A peça didática de BadenBaden sobre o acordo. In: Teatro Completo. Vol. V. Rio de Janeiro: Paz e Terra, 1992.

BUADES, Josep M. Entre mares. Uma interpretação da História Contemporânea da Península Ibérica. Vol. 1. São Paulo: Raimundo Lúlio, 2009.

CARLSON, MARVIN. Teorias do teatro. Estudo histórico-crítico, dos gregos à atualidade. Trad. de Gilson César Cardoso de Sousa. São Paulo: UNESP, 1997.

FREITAS, E. L. V. Dossiê Brecht. Teatro, estética e política. Cultura Crítica, São Paulo, v. 1 , no 1 , p. $45-63,1^{\circ}$. sem. de 2005.

FRYE, Northrop. Anatomia da crítica. Trad. de Péricles Eugênio da Silva Ramos. São Paulo: Cultrix, 1973.

GARCIA, Silvana. Teatro de militância. A intenção do popular no engajamento político. São Paulo: Perspectiva, 1990. (Série estudos).

JAMESON, Fredric. O método Brecht. Trad. de Maria Silvia Betti. Petrópolis: Vozes, 1999.

KAYSER, Wolfgang. O grotesco. Configuração na pintura e na literatura. Trad. de J. Guinsburg. São Paulo: Perspectiva, 2003.

LEY-PISCATOR, Maria. Le théâtre épique. In: Piscator et le théâtre politique. Paris: Payot, p. 153-156, 1983.

LLORENS, Vicente. La imagen de la patria en el destierro [1949]. In: Estudios y ensayos sobre el exilio republicano de 1939. Edição, estudo introdutório e notas de Manuel Aznar Soler. Sevilla: Renacimiento, 2006. 
MUSEO NACIONAL DEL PRADO. Enciclopedia online. Disponível em: <http://www.museodelprado.es/enciclopedia/enciclopedia-on-line/>. Acesso em: 19 out. 2011.

PISCATOR, ERWIN. Teatro político. Rio de Janeiro: Civilização Brasileira, 1968.

ROMERO SALVADÓ, Francisco. A Guerra Civil Espanhola. Trad. de Bárbara Duarte. Rio de Janeiro: Jorge Zahar, 2008.

ROSENFELD, Anatol. O teatro épico. 4a․ ed. São Paulo: Perspectiva, 2006. (Série debates).

. Teatro moderno. 2a ${ }^{\mathrm{a}}$. ed. São Paulo: Perspectiva, 2005. (Série debates).

ROUBINE, Jean-Jaqques. Introdução às grandes teorias do teatro. Trad. de André Telles. Rio de Janeiro: Jorge Zahar, 2003.

RUIZ RAMÓN, Francisco. Historia del teatro español siglo XX. 10ª․ ed. Madrid: Cátedra, 1995.

SALINAS DE MARICHAL, Solita. El mundo poético de Rafael Alberti. Madrid, Gredos, 1975

SALINAS, Pedro. Literatura española siglo XX. Madrid: Alianza, 2001.

SANTOS, Margareth dos. Goya en negro: una visión esperpéntica. 2000. 181 f. Dissertação (Mestrado em Letras) - Faculdade de Filosofia, Letras e Ciências Humanas, Universidade de São Paulo, São Paulo, 2000.

SZONDI, Peter. Teoria do drama moderno. Trad. de Luis Sérgio Repa. São Paulo: Cosac \& Naify, 2003.

VALLE-INCLÁN, Ramón María del. Luces de bohemia. Madrid: Espasa-Calpe, 1991, p. 168. 
VIVANCO, Luis Felipe. Introducción a la poesía española contemporánea. $2^{\underline{a}}$. ed. Madrid: Guadarrama, 1971.

WILLIAMS, Raimond. Tragédia moderna. São Paulo: Cosac \& Naify, 2002.

ZAHAREAS, Anthony N. El esperpento como proyecto estético. Insula, Madrid, no 531, p. 31-32, mar. de 1991.

ZARDOYA, Concha. Poesía española del siglo XX: estudios temáticos y estilísticos. $3^{\circ}$. vol. Madrid: Gredos, 1974. 